University of Chicago Law School

Chicago Unbound

Journal Articles

Faculty Scholarship

1989

\title{
The Supreme Court and the Jury: Voir Dire, Peremptory \\ Challenges, and the Review of Jury Verdicts
}

Albert Alschuler

Follow this and additional works at: https://chicagounbound.uchicago.edu/journal_articles

Part of the Law Commons

\section{Recommended Citation}

Albert Alschuler, "The Supreme Court and the Jury: Voir Dire, Peremptory Challenges, and the Review of Jury Verdicts," 56 University of Chicago Law Review 153 (1989).

This Article is brought to you for free and open access by the Faculty Scholarship at Chicago Unbound. It has been accepted for inclusion in Journal Articles by an authorized administrator of Chicago Unbound. For more information, please contact unbound@law.uchicago.edu. 


\title{
The Supreme Court and the Jury: Voir Dire, Peremptory Challenges, and the Review of Jury Verdicts
}

\author{
Albert W. Alschuler $\dagger$
}

The man who wants a jury has a bad case....

Oliver Wendell Holmes, Jr. ${ }^{\circledR}$

\section{Introduction: A Dissonant Chorus}

Our views of the jury are ambivalent. Defense attorneys, prosecutors, and judges typically proclaim their awe of the wisdom of the jury. They report that although jurors may not always master the technicalities of a case, they have an uncanny ability to grasp the truth and to provide common sense justice. ${ }^{2}$

On occasion, however, particularly when the practitioners speak of plea bargaining, their remarks about juries have a different tone. They report that submitting a case to a jury is very much like rolling dice. As sensitive and sophisticated professionals, these lawyers must avoid the dangers of trial. Even a "bad" plea agreement is likely to seem better than allowing a case to reach a jury-something that the lawyers describe as a plunge from an unknown height. ${ }^{3}$ The mixture of praise and mistrust that these prac-

† Wilson-Dickinson Professor of Law, The University of Chicago. I am grateful to Larry B. Kramer, John H. Langbein, William T. Pizzi, Judith Resnik, Carol Sanger, Stephen J. Schulhofer, Geoffrey R. Stone, H. Richard Uviller, Welsh S. White and the participants in a workshop at the University of Chicago Law School for valuable suggestions and to the Kirkland and Ellis Professorship Fund at the University of Chicago Law School for research support. Excerpts from this paper were presented at the dedication of the academic building of the John Jay College of Criminal Justice and appeared in 25 Crim L Bull at 57 (1989) under the title "The Overweight Schoolteacher from New Jersey and Other Tales: The Peremptory Challenge After Batson."

2 Mark DeWolfe Howe, ed, Holmes-Pollock Letters 74 (Belknap/Harvard, 2d ed 1961).

2 See Charles W. Joiner, From the Bench, in Rita James Simon, ed, The Jury System in America: A Critical Overview 145, 146 (Sage, 1975) ("I have generally, but not always, agreed with the jury verdict at the time it was rendered. But in each instance, except one, on reflection and on deeper analysis, I have decided the jury was correct."); Franklin Delano Strier, Through the Jurors' Eyes, 74 ABA J, 78, 81 (Oct 1, 1988) (statement of P. Terry Anderlini, President of the California State Bar, that jurors have an "uncanny ability to usually come up with the right result").

3 See Pamela J. Utz, Settling the Facts: Discretion and Negotiation in Criminal Court 66 (Lexington, 1978) (quoting a prosecutor: “[T]hose twelve people can't really handle it.”). 
titioners express brings to mind a wisecrack attributed to Mark Twain: "We have a jury system that is superior to any in the world, and its efficiency is only marred by the difficulty of finding twelve men everyday who don't know anything and can't read."4

When an observer suggests that the practitioners' descriptions of frequently erratic jury behavior are incompatible with their descriptions of the jury as a wondrous engine of justice, the practitioners nod and reply that the observer has missed the larger unity. In the tradition of romanticizing the jury, these practitioners' views are mysterious, poetic and incomprehensible.

The same ambivalence has shaped American law. Many American trial procedures, particularly those at the "front end" of the trial, manifest a substantial mistrust of jurors. The first two sections of this article focus on two of these procedures, the voir dire examination of prospective jurors and the peremptory challenge. The article also discusses other procedures and practices, including our patronizing rules of evidence, that bespeak limited faith in juries.

Procedures at the "back end" of the criminal trial, by contrast, tend to manifest confidence in jurors and to treat jury verdicts as sacrosanct. The third section of this article focuses primarily on the rule forbidding the impeachment of jury verdicts by jurors; it discusses as well our tolerance of inconsistent jury verdicts and our limited review of jury determinations of fact.

The article suggests that we have captured the worst of two worlds, creating burdensome, unnecessary and ineffective jury controls at the front end of the criminal trial while failing to imple-

Conflicting views of the jury are not new. In the late eighteenth century, various writers described jurors as "low and ignorant country people"; as "the meaner sort"; and as "the union of wisdom with integrity, impartiality with humanity." See P. J. R. King, "Illiterate Plebeians, Easily Misled": Jury Composition, Experience, and Behavior in Essex, 17351815, in J. S. Cockburn and Thomas A. Green, eds, Twelve Good Men and True: The Criminal Trial Jury in England, 1200-1800 254, 257 (Princeton, 1988) (citing M. Madan, Thoughts on Executive Justice, with Respect to the Criminal Laws, Particularly on the Circuits 142 (2d ed 1785); E. Cannon, ed, Adam Smith, Lectures on Justice, Police, Revenue and Arms 52 (Oxford, 1896); and the Chelmsford Chronicle (Dec 24, 1784)).

4 Although I have heard this remark attributed to Twain, I have been unable to locate it in his writing. For a more extended discussion of the jury, see Mark Twain, Roughing It 341-43 (American, 1872) ("When the peremptory challenges were all exhausted, a jury of twelve men was impaneled-a jury who swore that they had neither heard, read, talked about nor expressed an opinion concerning a murder which the very cattle in the corrals ... were cognizant of! . . . It actually came out afterward, that one of [the jurors] thought that incest and arson were the same thing."). See also id at 351 ("Trial by jury is the palladium of our liberties. I do not know what a palladium is, having never seen a palladium, but it is a good thing no doubt...."). 
ment badly needed controls at the back end. Although we have devoted substantial resources to implementing our front-end procedures, we generally have refused to expend significant resources to determine whether they have worked. Indeed, we often have turned aside clear evidence of their failure.

Initially, we subject jurors to lengthy, privacy-invading voir dire examinations, requiring them to answer questions that would be considered inappropriate and demeaning in other contexts. We also subject prospective jurors to peremptory challenges on grounds that in other settings would be considered discriminatory and unconstitutional. After affording jurors substantially less dignity than other public officials at the front end of the trial, however, we exempt them from the review generally applied to governmental officials at the back end. The Supreme Court has concluded that the constitutional prohibition of double jeopardy requires this exemption from judicial oversight when juries acquit, but the Constitution does not demand judicial blindness to unjust convictions.

In some respects, our jury system suffers from neglect bred by undeserved faith in its efficiency; in others, from misguided attempts at regulation. Both our failure to control the jury and our awkward attempts to do so have contributed to the decline of the jury trial. The American jury system encourages plea bargaining partly because lawyers doubt the jury's ability to do its job and believe that even a haphazard bargaining process is likely to yield a sounder result than a trial. ${ }^{6}$ The jury system also encourages plea bargaining in a less direct and probably more important way. Our mistrust of the jurors whom we extol has led us to surround the criminal trial with an extraordinarily expensive and cumbersome collection of courtroom procedures.

As we add gargoyles to an already garish temple of justice, we proclaim that we cannot admit more than a small minority of defendants to this sacred palace. Within the temple, legal priests

\footnotetext{
' See, for example, United States $v$ Ball, 163 US 662, 671 (1896); United States $v$ Scott, 437 US 82 (1978).

- Uncertainty reduction would provide a motive for plea bargaining even were a different mode of trial substituted for jury trial, but uncertainty reduction is likely to prove a stronger motivation for settlement in a jury system than in a nonjury system. When factfinding is entrusted to a body of untrained, casually selected judges who are almost never repeat players, procedural controls have only a limited ability to render the decisions of this body predictable. Because groups tend to regress toward the mean, however, the decisions of a twelve-person group should be-other things equal-more predictable than the decisions of an individual. The jury's size may offset to some degree the otherwise greater predictability of the actions of professional judges.
} 
baptize jurors, usher them in and out of the sanctuary as they debate how much the laity should know, and deliver incomprehensible sermons on the law. In the shadow of the temple, the same priests press the overwhelming majority of defendants to sacrifice the most basic of their rights, the right to trial. ${ }^{7}$

This article will focus on one paradigmatic Supreme Court decision in each of the three principal areas that it explores. In Turner $v$ Murray, ${ }^{8}$ the Court held that judges in some capital cases must question prospective jurors about their possible racial prejudices. The Turner decision illustrates some troublesome aspects of our voir dire procedure and also leads to more general observations concerning our frequently patronizing attitude toward jurors.

In Batson $v$ Kentucky, ${ }^{9}$ the Supreme Court considered the most undemocratic feature of our democratic trial system, ${ }^{10}$ the peremptory challenge. The frequent exercise of this challenge on the basis of crude group stereotypes ensures that, contrary to our rhetoric, juries rarely are composed of a defendant's peers and rarely reflect a fair cross section of the community. In Batson, the Supreme Court addressed an especially offensive and especially visible aspect of this practice-the use of peremptory challenges by prosecutors to exclude blacks from juries in cases involving black defendants. The Batson decision condemned only this narrowly defined form of discrimination and provided only a weak corrective for it. Nevertheless, the Supreme Court's effort to tame the peremptory challenge-but not very much-produced cumbersome procedures that will generate burdensome litigation for years to come. Moreover, while remedying one sort of discrimination, Batson invited and required others. The largest part of this article will

7 Compare Yale Kamisar, Equal Justice in the Gatehouses and Mansions of American Criminal Procedure, in Yale Kamisar, Fred Inbau, and Thurman Arnold, eds, Criminal Justice in Our Time 19 (U Va, 1965); John H. Langbein, Torture and Plea Bargaining, $46 \mathrm{U}$ Chi L Rev 3 (1978). I do not suggest that the substantive failings, procedural flaws, and high costs of jury trials provide the primary reasons for plea bargaining. Lawyers and judges sometimes invoke these concerns even when they are influenced in part by others, including considerations of their own comfort, convenience, and economic advantage. See my articles, The Prosecutor's Role in Plea Bargaining, 36 U Chi L Rev 50 (1968); The Defense Attorney's Role in Plea Bargaining, 84 Yale L J 1179 (1975); and The Trial Judge's Role in Plea Bargaining, 76 Colum L Rev 1059 (1976).

8 476 US 28 (1986).

476 US 79 (1986).

10 Dictionaries define democracy as "the principle of equality of rights, opportunity and treatment," as "lack of snobbery," and as "government by the people." See, for example, Webster's New World Dictionary of the American Language 390 (World, 1957). The jury system seems democratic in all these senses of the term. 
explore seven areas of litigation that the Batson decision has created. The article will endorse a conclusion that Justice Marshall reached in his concurring opinion: The Equal Protection Clause and the peremptory challenge are incompatible. ${ }^{11}$ Arbitrary exclusions from jury service have no place in a constitutional system grounded on concepts of equality and individual worth.

The Supreme Court's decision in Tanner $v$ United States ${ }^{12}$ illustrates the remarkable deference that courts generally afford jury verdicts. In this case, the Supreme Court held inadmissible the testimony of two members of a jury that several jurors had abused alcohol, marihuana, and cocaine repeatedly during a trial. When courts turn from front-end procedures to back-end review, considerations of judicial economy loom larger in their vision. This article will maintain that the Supreme Court misconstrued the Federal Rule of Evidence that it applied in Tanner and, more importantly, that both this rule and the earlier common law rule forbidding the impeachment of jury verdicts by jurors are unsound. Although all forms of juror misconduct should not lead to the invalidation of jury verdicts, misconduct of the sort alleged in Tanner should. Courts should decide whether to accord finality to jury verdicts without invoking see-no-evil evidentiary doctrines to shield themselves from knowledge.

Together, the three decisions that this article will examine provide an overview of our tangled sentiments concerning the jury and the strange procedures they have produced. We have devoted our energies and resources mostly to symbols while turning a blind eye to injustice.

\section{The Vorr Dire Examination of Prospective Jurors}

In the United States, the process of selecting a jury is often prolonged, sometimes consuming as much time as the trial. ${ }^{13}$ In one notorious case, lawyers examined more than 1000 prospective jurors over a four month period before finding twelve who could try the defendant. ${ }^{14}$ A substantial minority of state courts and a substantial majority of federal courts currently entrust the exami-

11 See 476 US at 108 (Marshall dissenting).

12483 US 107 (1987).

1s See Marcia Chambers, Who Should Pick Jurors, Attorneys or the Judge, NY Times B4 (June 13,1983 ) (in 20 percent of 462 cases studied by the New York Governor's Commission on Administration of Justice, voir dire took longer than the trial itself). 1971).

14 See Seale Jury Seated After 4 Months of Questioning, NY Times 43 (March 12, 
nation of prospective jurors to trial judges rather than counsel, thereby reducing the time devoted to voir dire. ${ }^{15}$ Nevertheless, an eleven-county study in New York (which retains attorney conducted voir dire) found that the average voir dire consumed 12.7 hours and 40 percent of the time devoted to trial. ${ }^{16}$

In examining prospective jurors, lawyers and judges probe their private attitudes and practices-asking, for example, about the jurors' religious beliefs, drinking habits, jobs, hobbies, and prior experience with lawyers, then asking about their relatives' jobs, experiences as crime victims, and arrest records as well. ${ }^{17} \mathrm{~A}$ recent Connecticut decision illustrated how far some judges believe that lawyers must be allowed to carry the process; the court reversed a defendant's conviction of stealing a family's Christmas gifts because the trial judge had refused to permit questions concerning the prospective jurors' "attitude toward Christmas."18

Lawyers' queries frequently are designed not to gain information but to make a point. For example, California defense attorneys sometimes ask before trial whether the defendant is guilty or innocent, expecting the honest answer, "I don't know." The lawyers then challenge the hapless juror who gave this answer on the ground that he or she departed from the presumption of innocence; the lawyers hope to impress other jurors with the importance of the presumption even if the challenge is disallowed. ${ }^{18}$ Every question asked during voir dire becomes part of a process that some thoughtful trial practitioners regard as scandalous; ${ }^{20}$ and although no single question may seem burdensome, it is appropri-

16 See V. Hale Starr and Mark McCormick, Jury Selection: An Attorney's Guide to Jury Law and Methods 39-40 (Little, Brown, 1985) (in thirteen states the judge alone conducts the voir dire examination; in eighteen states attorneys are primarily responsible for conducting this examination; in nineteen states the attorneys and judge share the examination; and 75 percent of federal judges permit no oral participation of counsel in the voir dire examination). For evidence that conduct of the voir dire examination by judges substantially reduces the time devoted to jury selection, see William $\mathrm{H}$. Levit et al, Expediting Voir Dire: An Empirical Study, 44 S Cal L Rev 916, 949 (1971); Note, Judge Conducted Voir Dire as a Time-Saving Trial Technique, 2 Rutgers-Camden L Rev 161, 184 (1970).

${ }^{18}$ Chambers, Who Should Pick Jurors at B4 (cited in note 13). Most of the federal judges who responded to a Federal Judicial Center survey estimated, however, that a "typical" voir dire consumed one hour or less. Gordon Bermant, Conduct of the Voir Dire Examination: Practices and Opinions of Federal District Judges 13 (Fed Judicial Center, 1977).

${ }_{17}$ See, for example, Ward Wagner, Jr., Art of Advocacy: Jury Selection MQ 4-50 (Matthew Bender, 1988) (suggesting model questions for attorneys to ask on voir dire).

${ }_{18}$ State v Barnes, 16 Conn App 333, 547 A2d 584, 588 (1988).

${ }^{18} \mathrm{As}$, incredibly, it may not be. See Charles R. Garry, Minimizing Racism in Jury Trials 85 (National Lawyers Guild, 1969).

20 See Edward Bennett Williams, Jury Selection-One Day Is Enough, 17 Student Lawyer J 24 (Oct 1971). 
ate to consider whether the benefits of asking this question exceed the costs.

Turner v Murray, ${ }^{21}$ decided by the Supreme Court in 1986, was a capital case in which the defendant asked the trial judge to submit the following question to prospective jurors:

The defendant, Willie Lloyd Turner, is a member of the Negro race. The victim, W. Jack Smith, Jr., was a white Caucasian. Will those facts prejudice you against Willie Lloyd Turner or affect your ability to render a fair and impartial verdict based solely on the evidence? ${ }^{22}$

The trial judge declined to ask this question. He did ask the prospective jurors whether they knew of any reason why they could not render a fair and impartial verdict. All the jurors responded "no."

Prior to Turner, the Supreme Court had held that a refusal to question prospective jurors about possible racial prejudice violated the Due Process Clause when the defendant was a black civil rights worker charged with a drug offense. ${ }^{24}$ It also had held that the omission of questions concerning racial prejudice was permissible when a black defendant was charged with robbing, assaulting, and attempting to murder a white security guard. ${ }^{25}$ In Turner, the Court ruled that the trial judge's refusal to inquire about possible racial prejudice violated the defendant's right to an impartial jury at the penalty phase of his capital trial. The Court vacated the defendant's death sentence while affirming his conviction of murder. ${ }^{26}$

Blacks who kill whites are sentenced to death with disproportionate frequency - a fact that the Supreme Court held in $\mathrm{McCles}$ key $v$ Kemp ${ }^{27}$ does not render their execution unconstitutional. ${ }^{28}$

21476 US 28 (1986).

22 Id at $30-31$.

23 Id at 31.

24 Ham v South Carolina, 409 US 524 (1973).

${ }^{2 s}$ Ristaino $v$ Ross, 424 US 589 (1976). To discern any distinction between Ham and Ristaino, one must have the legal mind. But see id at 596-97 (claiming that because Ham's defense was that he was being framed on account of his civil rights activity, "[r]acial issues . .. were inextricably bound up with the conduct of the trial" and concluding that "the circumstances . . . did not suggest a significant likelihood that racial prejudice might infect Ross's trial.").

26476 US at 37-38.

27481 US 279 (1987).

28 The apparent racial disparity in the imposition of capital punishment cannot be explained by relevant differences in the circumstances of the cases. See id at 354-59 (Blackmun dissenting). The decisions of prosecutors cause this disparity far more than the deci- 
Any procedure that offered even a marginal prospect of reducing this maladministration of the death penalty would have a strong claim to support. ${ }^{29}$ It is nevertheless appropriate to examine the way in which the decision in Turner encourages people to think of one another and the attitude toward juries that it expresses.

In Turner, the Supreme Court did not require an extended examination of prospective jurors to discover hidden or unrecognized biases. The defendant apparently was entitled only to a single question propounded to the entire jury panel. ${ }^{30}$ Although the Supreme Court described this procedure as "minimally intrusive,"31 it also seems minimally useful. One doubts that Lester Maddox, Orville Faubus, George Wallace, Theodore Bilbo or anyone else would have responded to the proposed question by confessing a bias likely to affect his or her resolution of a capital murder case. The function of the question, as of most of the questions that lawyers ask during voir dire, was to indoctrinate..$^{32}$ Its purpose was to admonish the jurors, reminding them of their responsibili-

sions of juries. See id at 350-51; McCleskey $v$ Zant, 580 F Supp 338, 367 (Table 3), 368-69 (ND Ga 1984), aff'd as McCleskey v Kemp, 753 F2d 877 (11th Cir 1985), aff'd, 481 US 279 (1987).

29 Whether the Sixth Amendment would require this procedure is a somewhat different question. One week after its decision in Turner, the Supreme Court apparently held that even an arbitrary exclusion of people from jury service on the basis of their viewpoint, politics, or ideology would not violate the Sixth Amendment's guarantee of trial by an impartial jury. It would be enough that the people who remained on the jury could be expected to " "conscientiously apply the law and find the facts." " Lockhart v McCree, 476 US 162, 178 (1986) (quoting Wainwright $v$ Witt, 469 US 412, 423 (1985)). In a case in which the Court found substantial justification for the challenged exclusion, the suggestion that the exclusion for cause of, say, all opponents of aid to the Contras would not violate the Sixth Amendment was an astonishing bit of overkill. In Turner, however, there was no reason to doubt that the defendant had been tried by an impartial jury of the kind that Lockhart required-one that had "conscientiously appl[ied] the law and [found] the facts." Four members of the jury were black, and one of them served as the jury's foreman. Turner, 476 US at 49 (Powell dissenting). See also Ross v Oklahoma, 108 S Ct 2273, 2276-77 (1988) ("Any claim that the jury was not impartial . . . must focus not on [a potential juror who was excluded] but on the jurors who ultimately sat.").

so The Court declared, "[T]he trial judge retains discretion as to the form and number of questions on the subject, including the decision whether to question the venire individually or collectively." 476 US at 37. See also id at 39 (Brennan dissenting) ("I, like the Court, am influenced by what the Court correctly describes as the 'ease' with which the risk may be minimized."); Ham v South Carolina, 409 US at 527 ("[E]ither of the brief, general questions urged by the petitioner would appear sufficient to focus the attention of prospective jurors on any racial prejudice they might entertain.").

31 Turner, 476 US at 37.

${ }^{32}$ See Dale W. Broeder, Voir Dire Examinations: An Empirical Study, $38 \mathrm{~S}$ Cal L Rev 503,522 (1965) ("Conservatively, about eighty per cent of the lawyers' voir dire time was spent indoctrinating, only twenty per cent in sifting out the favorable from the unfavorable veniremen .... [Nevertheless, i]ndoctrination did not often appear to succeed."). 
ties, and in effect to begin the trial before the trial began. ${ }^{33}$

Had I represented the State of Virginia in Turner, I would have been tempted to begin my oral argument before the Supreme Court with a question:

May it please the Court, the petitioner in this case, Willie Lloyd Turner, is a member of the Negro race. The victim, W. Jack Smith, Jr., was a white Caucasian. Chief Justice Burger and members of the Court, will those facts prejudice you against Willie Lloyd Turner or affect your ability to render a fair and impartial decision based solely on the law?

Resisting the temptation, I-like any other courteous lawyer-would not in fact have addressed this question to the Justices of the Supreme Court. Similarly, no lawyer would have asked it of a Virginia trial judge. Indeed, no respectful adult would ask another adult in polite conversation, "Pardon me. Are you a bigot?" Instead, the proposed question embodied a form of instruction typically reserved for children:

We're good Americans, aren't we, boys and girls? We would never judge a person on the basis of the color of his or her skin, would we? If you were deciding whether to convict a person accused of murder and to give him or her a lethal injection for a very nasty crime, this person's color wouldn't matter at all, would it?

The stakes were high enough in Turner that the defense attorney's question might have been justified; but we have become so accustomed to thinking of jurors as children that we may fail to recognize how patronizing the question is. ${ }^{34}$

The decision in Turner manifests a pattern of condescension toward jurors that appears in many of our practices and procedures. Although we invest jurors with important responsibilities, we seat them at the side of the courtroom in an area vaguely resembling the Peanut Gallery on the Howdy Doody Show. ${ }^{35}$ We

s3 See Susan E. Jones, Voir Dire and Jury Selection, 22 Trial 60, 66 (Sept 1986) ("If you handle voir dire well, by the time you reach opening statement, you will be preaching to the converted.").

s4 Sometimes an admonition not to yield to prejudice or to do other things that one knows one should not do might be useful and appreciated. Nevertheless, this sort of admonition should be exceptional, not routine. A respectful lawyer, for example, ordinarily would not admonish a trial judge to follow the law rather than his or her own predilections however strongly the lawyer suspected that this judge was inclined to bend or break the rules.

ss In Germany, by contrast, where lay people serve with professional judges on mixed tribunals, they sit at the head of the courtroom with the professional judges. See John $\mathrm{H}$. 
usually do not permit jurors to ask questions, ${ }^{36}$ and we do not permit them to explain their rulings. Like good children, good jurors are to be seen and not heard.

Even in white collar crime prosecutions so complex that lawyers bring computers to the courtroom to keep track of their evidence, jurors often are not permitted to take notes. ${ }^{37} \mathrm{~A}$ verdict apparently must be the product of atmospheric folk wisdom rather than careful study and reflection. Much of our law of evidence (including its central rules regarding hearsay and character evidence) rests on the proposition that the prejudicial impact of relevant information may outweigh its probative value - in other words, that although judges and rulemakers can understand the limited worth of this evidence, jurors who evaluate similarly fallible evidence in their everyday lives cannot. In accordance with the attitude toward jurors that our procedures commonly express, questions that would seem rude in other social contexts suddenly may appear unobjectionable when asked of prospective jurors.

To be sure, we do not always treat jurors as children. At the conclusion of the trial, we ask them to master legal concepts that, despite my best efforts, some of my students fail to grasp at the end of a lengthy course on criminal law. Consider this 110-word sentence from a "model" jury instruction included in the leading New York treatise on the subject:

To constitute a larceny, there must be an act that indicates the defendant's intention to obtain the property from its rightful owner by bringing about the transfer of the property or a legal interest in it to himself or to another person and to appropriate it to himself or to another person by exercising control over it or aiding a third party to exercise control over it permanently or for such an extended period of time or under such circumstances as to deprive its owner of the economic value or benefit of the property or to dispose of the property for himself or for the benefit of a third person. ${ }^{38}$

Langbein, Comparative Criminal Procedure: Germany 63 (West, 1977).

s6 See Comment, The Questioning of Witnesses by Jurors, 27 Am U L Rev 127, 132 (1977); Annotation, Propriety of Jurors Asking Questions in Open Court During Course of Trial, 31 ALR3d 872 (1970).

${ }^{37}$ See, for example, State $v$ Johnson, 632 SW2d 43, 45 (Mo App 1982); Commonwealth $v$ Pierce, $453 \mathrm{~Pa}$ 319, 309 A2d 371, 372 (1973); State v Groves, 311 S2d 230, 239 (La 1975), overruled on other grounds, State v Lee, 331 S2d 455 (La 1977); Annotation, Taking and Use of Trial Notes by Jury, 14 ALR3d 831, 838 (1967). A substantial number of courts, however, do permit note taking by jurors. See Annotation, 14 ALR3d at 834 .

${ }^{38}$ Budd G. Goodman and Howard G. Leventhal, 2 Charges to the Jury and Requests to 
Defenders of the jury system maintain that the process of explaining legal propositions to lay people helps to keep the law comprehensible, ${ }^{39}$ yet studies suggesting that jurors fail to understand half the instructions they receive ${ }^{40}$ do not always reflect badly on the jurors themselves. ${ }^{41}$ Jurors are not children; but with rare exceptions, neither are they legal scholars.

\section{The Peremptory Challenge}

Not only have we patronized jurors by treating them as children before and during trial; we also have insulted jurors by discriminating against them on racial and other invidious grounds. In Swain v Alabama, ${ }^{42}$ an all-white jury in Talledega County, Alabama, convicted a nineteen-year-old black man of raping a seventeen-year-old white woman and sentenced him to death. Since at least 1950, no black had served on a civil or criminal jury in Talledega County, and the prosecutor in Swain used six peremptory challenges to remove from the jury panel the only six blacks eligible to serve. ${ }^{43}$

In an opinion by Justice White, the Supreme Court affirmed the defendant's conviction and sentence. The Court distinguished between striking blacks in order to improve the prosecutor's likeli-

Charge in a Criminal Case $\S 43: 03$ at 222 (Callaghan, 1983) (emphasis in the original).

39 See, for example, Toni M. Massaro, Peremptories or Peers?-Rethinking Sixth Amendment Doctrine, Images, and Procedures, 64 NC L Rev 501, 514 (1986).

10 See, for example, Amiram Elwork, Bruce D. Sales, and James J. Alfini, Making Jury Instructions Understandable (Cambridge, 1982); Reid Hastie, Steven D. Penrod, and Nancy Pennington, Inside the Jury 80, 231 (Harvard, 1983); Robert P. Charrow and Veda R. Charrow, Making Legal Language Understandable: A Psycholinguistic Study of Jury Instructions, 79 Colum L Rev 1306, 1308-09 \& n 8 (1979); William W. Schwarzer, Communicating with Juries: Problems and Remedies, 69 Cal L Rev 731, 740-43 (1981); Laurence J. Severance and Elizabeth F. Loftus, Improving the Ability of Jurors to Comprehend and Apply Criminal Jury Instructions, 17 L \& Soc'y Rev 153 (1982).

11 Although much could be done to improve the comprehensibility of jury instructions, the problem of juror misunderstanding would be likely to persist. This misunderstanding probably stems more from the need to deliver a barrage of instructions on every legal issue potentially presented by various combinations of permissible factual findings than from the phrasing of particular instructions. In at least some cases, instructions may contain too much law for even capable and conscientious listeners to master. In accordance with our pattern of seeking mystic reassurance from juries rather than carefully considered judgments, jurors often are not permitted to consult written copies of the court's instructions during their deliberations. See, for example, United States v Conley, 503 F2d 520, 522 (8th Cir 1974); Martin v State, 260 Ind 490, 495-96, 296 NE2d 793, 797 (1973). This restriction, however, has been abandoned by a substantial and increasing number of courts. See, for example, United States $v$ Clavey, 565 F2d 111, 119 (7th Cir 1977) (allowing the jury to consult written instructions was not an abuse of the trial court's discretion).

42380 US 202 (1965).

1s Id at 205. 
hood of success at trial and striking them "for reasons wholly unrelated to the outcome of the particular case ... [simply] to deny the Negro the same right and opportunity to participate in the administration of justice enjoyed by the white population." 44 The Court recognized that, in the absence of tactical, trial-related objectives, the use of peremptory challenges to exclude blacks would be unconstitutional. ${ }^{45}$ The Court held, however, that the prosecutor's exclusion of all potential black jurors in a single case could not establish the proscribed motivation. Moreover, the Court concluded that the evidence before it failed to establish that the prosecutor was responsible for the exclusion of blacks in cases other than Swain. ${ }^{46}$

In places like Talledega County, the regime of peremptory challenges upheld in Swain reduced the requirement of nondiscrimination at earlier stages of the jury selection process to a mere symbol. Although, in a reaffirmation of democratic values, blacks and whites might be seated together on a panel of prospective jurors, a prosecutor could lawfully cause the blacks to disappear. Under Swain, the Constitution guaranteed minorities only an opportunity to reach the finals before a government officer discriminated against them.

Twenty-five years before Swain, the Supreme Court had said, "It is part of the established tradition in the use of juries as instruments of public justice that the jury be a body truly representative of the community."47 Nevertheless, Anglo-American juries long have been far less democratic than this rhetoric suggests. In eighteenth century Staffordshire, for example, three-quarters of the adult male population were insufficiently wealthy to meet the

4 Id at 224.

45 Id at 203-04.

4" The Court said that the "presumption protecting the prosecutor" might well be overcome if "the prosecutor ... in case after case, whatever the circumstances, whatever the crime and whoever the defendant or the victim may be, is responsible for the removal of Negroes who have been selected as qualified jurors ..., with the result that no Negroes ever serve on petit juries . . . " Id at 223-24. The frequency of the prosecutor's racially based exclusions was relevant under Swain only because it might supply proof of improper motivation, not because frequency itself determined the legality of the prosecutor's actions. As Justice White accurately observed in his concurring opinion in Batson $v$ Kentucky, 476 US $79,101 \mathrm{n} *$ (1986), it would not have been "inconsistent with Swain for the trial judge to invalidate peremptory challenges of blacks if the prosecutor, in response to an objection to his strikes, stated that he struck blacks because he believed they were not qualified to serve as jurors ...."

${ }^{47}$ Smith v Texas, 311 US 128, 130 (1940). But see Lockhart v McCree, 476 US 162, 174 (1986) (disregarding the language of Smith-and of the Sixth Amendment-and holding that the fair-cross-section requirement imposed by the Sixth Amendment right to jury trial does not extend to the jury but only to the panel from which the jury is selected). 
property qualification for jury service. ${ }^{48}$ Similarly, in eighteenth century Essex, only about 8 to 10 percent of the nonexempt heads of households qualified to serve on juries. ${ }^{40}$

During most of the history of the common law, peremptory challenges could at most have determined which members of a reasonably elite group of propertied men served on juries; and despite the very early origins of the peremptory challenge, ${ }^{50}$ challenges appear to have been rarely exercised in all of the periods of English history in which scholars have examined the question ${ }^{51}$ - so rarely that some scholars have concluded that challenges were simply un-

48 Douglas Hay, The Class Composition of the Palladium of Liberty: Trial Jurors in the Eighteenth Century, in Cockburn and Green, eds, Twelve Good Men and True at 305, 349, 357 (cited in note 3) ("Class Composition"). Only 2 percent of the people accused of crime (and none of the people charged with felony or theft) would have been eligible for jury service. Id at 350-51 (sample of all 181 defendants tried in Staffordshire in a single year).

40 See King, "Illiterate Plebeians, Easily Misled" at 261 (cited in note 3). Women, men over 70, peers, some apothecaries, some surgeons, registered seaman, some clerics and several other groups were either excluded or exempted from jury service. Hay, Class Composition at 321 (cited in note 48). The courts' power to empanel "talesmen" when an insufficient number of regularly qualified jurors were available raises the possibility that juries were more democratic than the "law on the books" concerning property qualifications suggested. The studies by King and Hay cited in this and the preceding footnote, however, reveal a close adherence to statutory requirements and an infrequent use of talesmen. Statutory qualifications for jury service were less demanding than those for serving as a justice of the peace, sitting in the House of Commons, or hunting game, however. See Hay, Class Composition at 349 (cited in note 48). In the context of the times, the English jury was a reasonably democratic institution.

so See Batson v Kentucky, 476 US 79, 118-20 (1986) (Burger dissenting).

s1 I suspect that the defendant's right to challenge prospective jurors was once a hybrid; the early challenge combined what we would today regard as the challenge for cause and the peremptory challenge. The self-informing jury was drawn from a small community, and personal enemies of the defendant were, in our terms, disqualified for cause. To conduct hearings on the issue of personal malice, however, would have been wasteful. When a defendant alleged malice on the part of a juror, the simplest course was to substitute another juror. The defendant thus assigned cause for every exclusion, but the court accepted the defendant's declaration as conclusive. Although the defendant's challenge was "for cause," it was also "peremptory." On this view, the early peremptory challenge manifested no faith in the defendant's ability to detect biased jurors through hunch or intuition; the peremptory challenge was simply an economical means of accomplishing objectives that we now pursue by permitting challenges for cause. See Henri Bracton, 2 On the Laws and Customs of England 405 (Harvard, 1968) (Samuel E. Thorne translation) ("[L]et the justice inform the indicted man that if he suspects any of the twelve jurors he may remove them for just cause, and let the same be said of the [jurors of] the vills, as where there are deadly enmities between some of them and the indicted man ... ; if there is ground for suspicion all are to be removed, that the inquiry may proceed free of all doubts.").

Thomas A. Green, who knows much more about the early jury than I do (and probably as much as anyone does), agrees that my speculation concerning the hybrid nature of the early challenge is plausible but knows of no source that might confirm it. Telephone interview, Nov 15, 1988. If my surmise is accurate, the judges who created the challenge might be surprised to learn of the tactical games that it now enables professional advocates to play. 
available in ordinary criminal cases. ${ }^{52}$

The use of peremptory challenges has remained infrequent in modern England. A 1979 study of English criminal trials reported, "[T]he right of challenge was exercised [by either the defense or the prosecution ${ }^{58}$ in no more than one trial in seven, and only exceptionally was there more than a single challenge in a case." The relative homogeneity of English society may largely explain why peremptory challenges have been less used in England than in America, but there have been other reasons as well. The number of peremptory challenges allowed the defense has declined substantially over the course of English history and was finally lowered to three in 1977. Nonunanimous, ten-to-two jury verdicts are permitted. Property qualifications persisted until 1972, and these requirements effectively excluded most women from jury service. ${ }^{55}$ Moreover, a study of Birmingham juries indicated that nonrandom jury selection by court officials contributed to a continuing underrepresentation of women and minorities after $1972 .{ }^{56}$ Finally, even the limited and infrequently utilized voir dire examination that counsel historically had been allowed was abolished in $1973 .^{57}$

In the United States, as broadened standards of eligibility for

${ }^{52}$ An examination of late fourteenth century English jury records by J. B. Post uncovered no trace of the peremptory challenge at all. Post reported that, apart from people on the jury list who failed to appear, the first twelve people on the list almost invariably were empaneled. He concluded that, despite "the received opinion of the lawyers," challenges were not available in ordinary criminal cases. J. B. Post, Jury Lists and Juries in the Late Fourteenth Century, in Cockburn and Green, Twelve Good Men and True at 71 (cited in note 3). Thomas A. Green noted the similar rarity of peremptory challenges throughout the early history of the jury trial. In Green's view, the fact that defendants and jurors came from different social classes and ordinarily did not know one another could not entirely explain the absence of peremptory challenges. He concluded that defendants either were unaware of the challenges authorized by law or were discouraged from exercising them. Thomas Andrew Green, Verdict According to Conscience: Perspectives on the English Criminal Trial Jury 1200-1800 133-34 (Chicago, 1985). A study of the eighteenth century English jury reported that the right of challenge was "rarely used" in this period as well. King, "Illiterate Plebeians, Easily Misled" at 277 (cited in note 3).

${ }^{83}$ As a formal matter, English procedure affords only the defendant a right to challenge prospective jurors peremptorily. In practice, however, the Crown's power to ask prospective jurors to "stand by" affords the Crown a broader power to exclude prospective jurors than the peremptory challenge gives the defendant. See Graham Hughes, English Criminal Justice: Is It Better Than Ours?, 26 Ariz L Rev 507, 593-94 (1984).

st John Baldwin and Michael McConville, Jury Trials 92-93 n 15 (Oxford, 1979). See also Hughes, 26 Ariz L Rev at $593 \mathrm{n} 399$ (cited in note 53) (describing the similar findings of the Morris Committee on Juries but indicating a more frequent use of the peremptory challenge in London).

${ }^{85}$ Hughes, 26 Ariz $L$ Rev at 591 (cited in note 53).

${ }^{86}$ Baldwin and McConville, Jury Trials at 97-98 (cited in note 54).

${ }^{87}$ For a description of all of these developments and useful citations, see Hughes, 26 Ariz L Rev at 591-95 (cited in note 53). 
jury service manifested democratic faith in the popular administration of justice, the peremptory challenge manifested countervailing doubt, mistrust, and ambivalence. The persistence of the challenge typically ensured that a jury would not reflect a fair cross section of the community or include too many of a defendant's peers. Although less sweeping than the formal statutory disqualifications that legislatures had abandoned and that courts had held unconstitutional, the peremptory challenge was in some ways more troublesome. This challenge could be exercised on any ground, including one that a legislature would not approve or a court uphold. Lawyers could use a power delegated by government to do in one case after another what the government could not do uniformly. Moreover, unlike a statutory disqualification, the peremptory challenge not only identified the people whom it disqualified but also made them aware of their exclusion. In places like Talledega County, it might have been kinder to save blacks the trouble of showing up.

The years following the decision in Swain $v$ Alabama witnessed a concerted national effort to eliminate racial discrimination from most aspects of American life; and by 1986, the truly unrestricted, truly peremptory challenge apparently had become the last bastion of undisguised racial discrimination in the criminal justice system. The Supreme Court's opinion in Batson $v$ Kentucky"s began by announcing that the Court would "reexamine that portion of Swain v. Alabama . . . concerning the evidentiary burden placed on a criminal defendant who claims that he has been denied equal protection through the State's use of peremptory challenges to exclude members of his race from the petit jury." Justice Powell's opinion for the Court concluded:

Although a prosecutor ordinarily is entitled to exercise permitted peremptory challenges "for any reason at all, as long as that reason is related to his view concerning the outcome" of the case to be tried, . . . the Equal Protection Clause forbids the prosecutor to challenge potential jurors solely on account of their race or on the assumption that black jurors as a group will be unable impartially to consider the State's case against a black defendant. ${ }^{60}$

The Court characterized the issue in Batson merely as one of

s8 476 US 79 (1986).

${ }^{58}$ Id at 82.

${ }^{60}$ Id at 89 (quoting United States $v$ Robinson, 421 F Supp 467, 473 (D Conn 1976), mandamus granted sub nom United States $v$ Newman, 549 F2d 240 (2d Cir 1977)). 
the "evidentiary burden" that a defendant must assume to establish a prosecutor's discriminatory purpose, ruling that proof of a pattern of exclusion extending over more than one case was no longer necessary. ${ }^{61}$ This characterization of the issue, however, was misleading. The Batson decision not only overruled Swain on an issue of proof but also (and more importantly) altered what a defendant was required to prove. The Court rejected the Swain opinion's limited concept of impermissible purpose and held that a prosecutor could violate the Equal Protection Clause by excluding blacks for trial-related reasons. ${ }^{62} \mathrm{~A}$ desire to deny minorities a voice in the administration of criminal justice whatever the circumstances of the case was no longer the sine qua non of a constitutional violation. Batson revised not simply the means of proving an improper purpose but the concept of discriminatory purpose itself.

The Court's characterization of the issue in Batson was misleading in a second respect as well. The Court described the motivations of prosecutors in a way that insulted them and exhibited an apparent misunderstanding of the litigation process. A prosecutor who peremptorily excludes blacks from a jury usually does not act "on the assumption that black jurors as a group will be unable impartially to consider the State's case against a black defendant" ${ }^{\prime 3}$ or, as the Court later put it, on "the assumption that [black jurors] will be biased in a particular case simply because the defendant is black." her use of race as a predictor by saying:

I do not doubt that black jurors can fairly try a case against a black defendant. My goal, however, is to secure a jury that will prove as receptive to the state's case as possible. I must exercise my peremptory challenges on the basis of limited information; and my experience has been that, although both blacks and whites are generally fair-minded and conscientious, whites tend to be more favorable to the state's position in this sort of case than blacks.

Read literally, Batson might not preclude racially grounded challenges by a prosecutor who could honestly make this statement; this prosecutor would not believe that black jurors are "bi-

id Id at 82,96 .

62 Id at 100. See also id at 134-37 (Rehnquist dissenting).

${ }^{83}$ Id at 89.

64 Id at 97 . 
ased" or "unable impartially to consider the State's case" simply because these jurors share the defendant's race. The goal of this prosecutor, as of most trial lawyers, would be to obtain a favorable rather than an unbiased jury. Nevertheless, this prosecutor's motivation is undoubtedly among those that the Court meant to condemn. ${ }^{65}$

Although Batson brought to an end the Supreme Court's formal approval of some racial discrimination by prosecutors, the Court limited the peremptory challenge only narrowly. Restricting inquiry into a prosecutor's motives both procedurally and substantively, the Court created what William Pizzi has called an "enforcement nightmare." resolution may require the judiciary to draw lines every bit as ugly and invidious as those that the Court condemned.

A review of seven issues that Batson left open will reveal the substantial economic and human costs that the decision imposes and the limited gain that it may yield. In the end, there appears to be no escape from a conclusion that Justice Marshall reached in a concurring opinion in Batson, ${ }^{67}$ that Chief Justice Burger voiced in a dissenting opinion, ${ }^{68}$ and that the Supreme Court itself apparently had accepted in Swain:69 Applying the Equal Protection Clause to the jury selection process in the same way that the Court has applied it to other governmental activities would abolish the peremptory challenge altogether.

Although Chief Justice Burger and the Court in Swain saw the value of preserving peremptory challenges as a reason for limiting the reach of the Equal Protection Clause, they failed to put first

os The Court's misleading description of the motivation of prosecutors who exclude blacks for trial-related reasons facilitated its condemnation of this motivation. A belief that black jurors "will be biased in a particular case simply because the defendant is black" would be false and would manifest racial bigotry. Nevertheless, just as blacks and whites may favor Jesse Jackson for President in different ratios, blacks and whites may-if regarded collectively and statistically-approach the issues that arise in some criminal cases differently. See Katherine Goldwasser, Limiting a Defendant's Use of Peremptory Challenges, 102 Harv L Rev 808, 834-35 n 165 (1989) (collecting sources). The Supreme Court did not suggest that a prosecutor who considered race an empirically significant predictor would be personally biased or even wrong. In Batson, the Court directed prosecutors to act in a way that may in fact diminish their ability to win their cases-a circumstance that bears on the likelihood that they will exploit the loopholes that the opinion affords.

so William T. Pizzi, Batson v Kentucky: Curing the Disease but Killing the Patient, 1987 S Ct Rev 97, 134.

67 476 US 107-08 (Marshall concurring).

68 Id at 123-28 (Burger dissenting). This portion of Chief Justice Burger's opinion is discussed in text at notes $178-82$.

69 See 380 US at 221-22. 
principles first. Peremptory challenges ensure the selection of jurors on the basis of insulting stereotypes without substantially advancing the goal of making juries more impartial. The Equal Protection Clause forbids the arbitrary classification of human beings, and peremptory challenges are inherently arbitrary. Even when exercised on grounds other than race, these challenges are unconstitutional. ${ }^{70}$

\section{A. Prima Facie Proof of Discriminatory Purpose}

Batson established a two-stage procedure for evaluating claims of discrimination in the use of peremptory challenges. A defendant must "establish a prima facie case of purposeful discrimination" before the burden shifts to the prosecutor to "come forward with a neutral explanation for challenging black jurors."71 The Court said that "the trial court should consider all relevant circumstances" in deciding whether a prima facie case has been shown, adding that the prosecutor's statements during the examination of prospective jurors might support "an inference of discriminatory purpose."72 A prosecutor usually fails to provide verbal hints of a discriminatory goal, however, and the Court did not indicate how many blacks this prosecutor might strike in an ordinary case before his or her actions would exhibit an apparent pattern of discrimination requiring explanation.

In other contexts, the Court has suggested that a prima facie case requires proof of a statistically significant disparity between the number of minorities selected by an actor and the number that a random process would have been expected to produce. ${ }^{73}$ Nevertheless, the "expected" number of minorities on a twelve-person

${ }^{70}$ For more rigorous analysis of this issue, see text at notes 173-99. Although, from his own perspective, a prosecutor may have a rational basis for striking black prospective jurors (see note 63 and accompanying text), a rational basis is insufficient to support an invidious racial classification. See, for example, Loving $v$ Virginia, 388 US 1, 8-9 (1967). Moreover, the issue is whether the prosecutor's classification adequately advances a public or governmental interest, not whether it advances the prosecutor's own interest in victory at trial. In other words, the issue is whether-in a system in which potential jurors who exhibit partiality are subject to challenge for cause-a prosecutor's gamesmanship in removing jurors who do not exhibit this partiality coupled with similar gamesmanship on the part of his opponent yields a better jury.

7 See 476 US at $96-97$.

72 Id.

${ }^{73}$ See, for example, Castaneda v Partida, 430 US 482, 496-97 n 17 (1977) ("As a general rule for ... large samples, if the difference between the expected value and the observed value is greater than two or three standard deviations, then the hypothesis that the jury drawing was random would be suspect to a social scientist."). 
jury is so small in most jurisdictions that even when no minorities in fact serve on a jury this circumstance cannot establish a statistically significant disparity. The Supreme Court emphasized in Batson that prima facie proof does not require evidence of discrimination extending over more than one case. ${ }^{74}$ Rather than focus on the final composition of the jury, a court might consider the likelihood that a prosecutor's peremptory challenges would have excluded the number of minorities that they did exclude if these challenges had been exercised by lot. This approach might permit the development of useful statistical proof, but the Supreme Court did not explore this possibility. In essence, the Court's requirement of a prima facie case left lower court judges at large to determine when "things look bad."

Some courts have held that a prosecutor's exclusion of the only two ${ }^{75}$ or even the only three ${ }^{76}$ minorities on a jury panel does not establish a prima facie case of discrimination. ${ }^{77}$ Courts also have concluded that when a prosecutor fails to challenge all the potential minority jurors whom he or she might, the number whom he or she may challenge without explanation increases. ${ }^{78}$ Indeed, language in Justice White's concurring opinion in Batson-language that probably should not be read literally-suggests that so long as a prosecutor allows even one black whom he or she might have challenged to serve on a jury, the exclusion of all other blacks is constitutional. ${ }^{79}$

74476 US at 95-96.

${ }^{78}$ See, for example, United States $v$ Vaccaro, 816 F2d 443, 457 (9th Cir 1987); People $v$ Rousseau, 129 Cal App 3d 526, 536-37, 179 Cal Rptr 892, 897-98 (1982) (interpreting People $v$ Wheeler, 22 Cal3d 258, 148 Cal Rptr 890 (1978), a decision similar to Batson).

76 See Commonwealth $v$ Robinson, 382 Mass 189, 415 NE2d 805, 809-10 (1981) (prosecutor struck three of the four minority group members of a jury panel peremptorily and the remaining minority for cause-no prima facie case under Commonwealth v Soares, 377 Mass 461, 387 NE2d 499 (1979), a ruling similar to Batson).

77 But see Mitchell $v$ State, 295 Ark 341, 750 SW2d 936, 940 (1988), and Stanley $v$ State, 313 Md 50, 542 A2d 1267, 1283-1285 (Md Ct App 1988), both of which held that the exclusion of one minority group member is sufficient to establish a prima facie case when this juror is the only member of the defendant's race on the panel of prospective jurors.

${ }^{78}$ In addition to the cases cited in note 79, see Note, Batson v. Kentucky and the Prosecutorial Peremptory Challenge: Arbitrary and Capricious Equal Protection?, 74 Va L Rev 811, 821 \& n 74 (1988).

${ }^{70}$ Justice White described the motivation that Batson ruled impermissible as a "belief that no black citizen could be a satisfactory juror or fairly try a black defendant," as "the assumption that no black juror could fairly judge a black defendant," and as "the view that all blacks should be eliminated from the entire venire." 476 US at 101 (White concurring). If read literally, these statements suggest that a prosecutor's willingness to permit any black to serve on a jury-for example, a black known to the prosecutor as a conservative, an opponent of affirmative action, and an advocate of increased criminal penalties-would permit 
The success or failure of the Batson decision may not depend solely upon the ability of courts to detect and sanction prosecutorial misbehavior. The Court in Swain told prosecutors that they might lawfully exclude blacks from a jury for trial-related reasons; Batson informed them that this tactical exclusion was no longer permissible. Because most prosecutors will probably comply with the Supreme Court's decision in good faith, Batson may work a significant change in American trial practice. ${ }^{80}$ I suspect in fact that it has.

Nevertheless, some prosecutors may seek to evade the requirements of the Batson decision; and unlike the somewhat comparable requirement of prima facie proof in civil lawsuits alleging unlawful discrimination, the requirement of a prima facie case limits a defendant's ability to discover the motives of a prosecutor suspected of discrimination. In a Title VII action or other civil lawsuit alleging discrimination, the plaintiff may obtain pretrial discovery from the defendant before attempting to present a prima facie case at trial. Because a criminal defendant alleging discrimination in the exercise of peremptory challenges has no comparable discovery opportunity, the requirement of a prima facie case serves a gatekeeping function not served by the seemingly comparable requirement in civil cases. This procedural hurdle may offer substantial comfort to a prosecutor who wishes to continue pre-Batson

the prosecutor to exclude all other blacks. See State v Peck, 719 SW2d 553, 556 (Tenn Crim App 1986) (no prima facie case because the prosecutor did not exclude "all members of defendant's race"); United States $v$ Montgomery, 819 F2d 847, 851 (8th Cir 1987) ("The fact that the government accepted a jury which included two blacks, when it could have used its remaining peremptory challenges to strike these potential jurors, shows that the government did not attempt to exclude all blacks, or as many blacks as it could, from the jury."); United States v Dennis, 804 F2d 1208, 1211 (11th Cir 1986) (prosecutor struck three blacks and accepted two-no prima facie showing of discrimination); United States $v$ David, 662 F Supp 244, 246 (N D Ga 1987), aff'd, 844 F2d 767 (11th Cir 1988) (prosecutor struck two of three blacks on the jury panel and one of two blacks on the alternate panel-no prima facie showing of discrimination because "(1) the number of black persons on the regular panel was small and (2) the prosecutor could have, but did not, strike all of the black members of that panel"). But see Fleming $v$ Kemp, 794 F2d 1478, 1483 (11th Cir 1986) ("nothing in Batson compels the . . . conclusion that constitutional guarantees are never abridged if all black jurors but one or two are struck because of their race"); United States v Battle, 836 F2d 1084, 1086 (8th Cir 1987) ("the striking of a single black juror for racial reasons violates the Equal Protection Clause, even though other black jurors are seated"); Stanley v State, 313 Md 50, 542 A2d 1267, 1278-79 (Md 1988) (prima facie case established by prosecutor's use of eight of his ten peremptory challenges against blacks although three blacks served on the defendant's jury).

${ }^{\text {so }}$ But see Oliver Wendell Holmes, The Path of the Law, 10 Harv L Rev 457, 459 (1897) (arguing that law must be judged from the perspective of a bad man who wishes only to evade it). 
patterns of discrimination. In every case, Batson may afford this prosecutor one or two "free shots"-opportunities to discriminate against blacks without accounting for his or her actions. When only one or two blacks appear on the panel of prospective jurors, the prosecutor may need no more ammunition. Moreover, whenever the prosecutor holds his or her fire and allows one or two blacks to serve on a jury, he or she may gain additional opportunities to discriminate. ${ }^{81}$

\section{B. Racially Neutral Explanation}

When a defendant establishes a prima facie case of discrimination under Batson, a prosecutor may rebut it by "com[ing] forward with a neutral explanation for challenging black jurors."82 Trial courts must determine whether the reasons offered by prosecutors are truthful, are sufficiently independent of race to qualify as "neutral," and are otherwise satisfactory. ${ }^{83}$ When these courts

B1 The South Carolina Supreme Court has withheld "free shots" from South Carolina prosecutors. It has urged trial courts to require prosecutors to supply reasons whenever they exclude members of a defendant's race from a jury. State $v$ Jones, 293 SC 54, 358 SE2d 701, 703 (1987). See also State v Holloway, 44 Crim L Rptr 2390 (Conn 1989) (grounding a requirement that a prosecutor explain every exclusion of jurors of the same race as the defendant on the court's "inherent supervisory authority over the administration of justice"). Although the South Carolina court's requirement seems broad enough to include cases in which white defendants challenge the exclusion of prospective white jurors, one doubts that the court will extend its requirement to these cases. Demanding a statement of reasons for every peremptory challenge of a white juror when a case involves a white defendant and for every peremptory challenge of a black juror when a case involves a black defendant would come close to abolishing the peremptory challenge; there would be little reason not to go the distance. Although the South Carolina procedure saves trial courts from one burden-inquiry into the adequacy of preliminary showings of discrimination-it imposes another. When a case involves a minority defendant, the court must record reasons for the exclusion of every minority juror and must rule on the adequacy of these reasons. This procedure-demanding that prosecutors explain every exclusion of blacks but no exclusion of whites-may seem not only costly but patronizing. Still, the South Carolina procedure appears preferable to that contemplated by Batson. In the end, any procedure that stops short of demanding cause for every exclusion of blacks and whites is likely to substitute new forms of discrimination for old.

8246 US at 97.

as The Court said that "the prosecutor's explanation need not rise to the level justifying exercise of a challenge for cause," 476 US at 97, that it must be "a "clear and reasonably specific' explanation of . . 'legitimate reasons," " id at 98 n 20 (quoting Texas Dept. of Community Affairs v Burdine, 450 US 248, 258 (1981)), and that it must be "related to the particular case to be tried." Id at 98 . One wonders whether the last requirement was meant to preclude prosecutors from using general selection criteria applicable to all cases. For example, a prosecutor attuned to courthouse folklore might explain his exclusion of a black juror by saying, "I follow the 'P' rule. That is, I never accept a juror whose occupation begins with the letter 'P,' and I struck this prospective juror because she is a plumber." The prosecutor might be able to demonstrate the truthfulness of his statement by showing that 
prove too tolerant of prosecutorial explanations, appellate proceedings and retrials become necessary.

The requirement of a racially neutral explanation poses the conundrums that a requirement of nondiscriminatory purpose always poses. Whether the presence of one neutral reason is sufficient, whether the prosecutor must have been wholly uninfluenced by race, or whether the court must probe the prosecutor's psyche deeply enough to determine how he or she would have treated a white juror who exhibited similar characteristics is uncertain. ${ }^{84}$ Judging whether the prosecutor would have treated a white juror in the same way as a black juror could prove especially problematic when, even apart from color, few whites would have been likely to share some of the excluded juror's characteristics. ${ }^{85}$

in many past cases he consistently had excluded both black and white prospective jurors whose occupations began with the letter "P." Under Batson, the fact that the prosecutor's challenges were exercised on a racially neutral basis probably should justify them, but the reason offered for the challenges seems neither "legitimate" nor "related to the particular case to be tried." Noting the Court's observation that the prosecutor's statement of reasons "need not rise to the level justifying exercise of a challenge for cause," Chief Justice Burger protested, "I am at a loss to discern the governing principles here. A 'clear and reasonably specific' explanation of 'legitimate reasons' for exercising the challenge will be difficult to distinguish from a challenge for cause." Id at 127 (Burger dissenting). See State $v$ Butler, 731 SW2d 265, 272 (Mo App 1987) (prosecutor explained that he rejected a prospective juror because, as a nurse, she would tend to be "compassionate and thus inclined to feel sorry for defendants"-explanation held inadequate); Williams $v$ State, 507 NE2d 997, 999 (Ind App 1987) (prosecutor explained that he rejected a prospective juror because she was a social worker and therefore "might have had a liberal view of sexual behavior" that would affect her judgment in a rape case-explanation held adequate); Slappy $v$ State, 503 S2d 350,355 (Fla App 1987) (prosecutor explained that he rejected two prospective jurors because they were schoolteachers, a position indicating "liberalism" explanation held inadequate); Chisolm $v$ State, 529 S2d 635, 638 (Miss 1988)(prosecutor explained that he rejected two prospective jurors because they were associated with radio and television stations that had broadcast anti-law enforcement programs-explanation held adequate; Batson does not preclude "absurd" challenges so long as they are not based on race).

84 Some prosecutors have admitted mixed racial and nonracial motives. After excluding the only four prospective black jurors in a robbery case, a federal prosecutor explained one challenge by noting that the excluded juror had come to court in bluejeans, indicating to the prosecutor the juror's lack of "respect for the system." The prosecutor added, "I thought [this prospective juror] lived in the [defendant's] neighborhood-he's black, too, . . . and I thought he might identify with him too much." Although the Ninth Circuit did not decide whether this explanation justified the prosecutor's strike, it noted that some of the prosecutor's reasons seemed proper while one-the fear that the prospective juror's race would lead him to identify with the defendant-was plainly improper. United States $v$ Thompson, 827 F2d 1254, 1256 n 1, 1260 (9th Cir 1987).

8s A prosecutor in the District of Columbia once told me that he would not attempt to exclude all blacks from a jury even in a jurisdiction other than his in which this effort might not prove futile. "But I'll tell you this," the prosecutor added. "I won't let a street dude on one of my juries." Were this prosecutor honestly to explain a peremptory challenge by declaring, "I did not strike this person because he's black; I struck him because he's a street dude," some psychoanalysis might be necessary to determine the adequacy of his explana- 
Moreover, even if it could be determined that a prosecutor probably would have excluded a white juror with a characteristic like one that had led the prosecutor to exclude one or more blacks, the characteristic might be such a close proxy for race that, in the language of the Batson opinion, it would not supply a "neutral explanation for challenging black jurors." plain a peremptory challenge by noting that the excluded black juror lives in the same neighborhood as the defendant, lives in a similar neighborhood, is economically disadvantaged, is unemployed, is of the same religious faith as the defendant, has failed to finish high school, has been arrested, or is related to someone who has been arrested. Prospective jurors who share the defendant's race may share some of his or her other characteristics; and when prosecutors have focused on these other characteristics, courts often have upheld their peremptory strikes. ${ }^{87}$

Finally, courts must determine what reasons for exclusion are disingenuous or pretextual-a particularly difficult task when a prosecutor relies on a juror's asserted mannerisms to justify an exclusion. A black who wishes to serve on a jury must be careful to look directly at the prosecutor. The Fifth Circuit has upheld an exclusion grounded primarily on a prospective juror's failure to maintain eye contact. ${ }^{88}$ The prospective juror must not look too much, however. The Seventh Circuit has upheld an exclusion that a prosecutor explained by saying, "Mr. Declinton [sic, Declinton was the prospective juror's first name] was sitting directly to my right, only a space of approximately four feet from me, and both

tion. The prosecutor might declare that most blacks are not street dudes and that some whites are, but he might find it more difficult to affirm that his characterization was wholly uninfluenced by the prospective juror's race. The prosecutor might admit in fact that he was influenced in part by the prospective juror's hairstyle and manner of speech, characteristics unlikely to be duplicated precisely in many white jurors. As Justice Marshall observed in his concurring opinion in Batson, "Even if all parties approach the Court's mandate with the best of conscious intentions, that mandate requires them to confront and overcome their own racism ... - a challenge I doubt all of them can meet." 476 US at 106. For a discussion of the difficulty of resolving the "counterfactual conditionals" posed by some concepts of discriminatory purpose, see David A. Strauss, Discriminatory Intent and the Taming of Brown, 56 U Chi L Rev (forthcoming, 1989).

so 476 US at 97.

${ }^{87}$ See, for example, United States $v$ Cartlidge, 808 F2d 1064, 1070 (5th Cir 1987) (exclusion because prospective juror was "young, single, and unemployed" upheld); Taitano $v$ Commonwealth, 4 Va App 342, 358 SE2d 590, 592-93 (1987) (exclusion because prospective jurors lived in the same neighborhood as the defendant or in "areas of 'high crime" " upheld). But see State $v$ Gilmore, 103 NJ 508, 542-43, 511 A2d 1150, 1168 (1986) (exclusion based on the assumption that prospective jurors, like the defendant, were Baptists held invalid).

8s Cartlidge, 808 F2d at 1071. 
yesterday and today he spent a very great deal of time in examining me in a way which $I$ felt was in the end becoming rather hostile."

Courts have upheld exclusions grounded on a prospective juror's "posture and demeanor,"90 "poor attitude in answering voir dire questions," "nodding . . . a little bit too much toward [defense counsel] and not enough towards me," "demeanor and how he answered the questions," as and even exuding "something [that] seemed unfavorable."94 The Supreme Court, however, may attempt to limit the courts' toleration of possibly pretextual explanations by prosecutors. It has accepted for review a capital case in which the Texas Court of Criminal Appeals upheld the exclusion of five prospective black jurors, including one who was challenged only because he had been an employee of the United States Postal Service for thirteen years. The prosecutor explained that she had not "had very good luck with postal employees."

Even when prosecutors are forthcoming, determining the adequacy of their explanations is a difficult and burdensome task, and prosecutors may not always be forthcoming. For some prosecutors, Batson's message may appear to be: When your quota of free shots is exhausted, you must make up some plausible reasons. ${ }^{96}$

89 United States v Mathews, 803 F2d 325, 331-32 (7th Cir 1986), rev'd on other grounds, 108 S Ct 883 (1988).

so United States v Forbes, 816 F2d 1006, 1010-11 (5th Cir 1987).

${ }^{91}$ United States v Vaccaro, 816 F2d 443, 457 (9th Cir 1987).

${ }^{92}$ Chambers v State, 724 SW2d 440, 442 (Tex App 1987).

${ }^{93}$ People v Talley, 152 Ill App3d 971, 504 NE2d 1318, 1327 (1987).

96 Rodgers v State, 725 SW2d 477, 480-81 (Tex App 1987).

${ }^{85}$ Tompkins v State, 1987 WL 906 (Tex Crim App) (unreleased slip opinion), cert granted, 108 S Ct 1727 (1988). See also United States v David, 662 F Supp 244 (ND Ga 1987), affd, 844 F2d 767 (11th Cir 1988) (prosecutor explained his exclusion of a black juror by saying that government employees tended to be naive-court upheld the exclusion on the ground that because the number of potential black jurors was small and the prosecutor had permitted one of them to serve, the defendant had not established a prima facie case of discrimination).

${ }^{96}$ William Pizzi's description of Branch v State, 526 S2d 605 (Ala Crim App 1986), remanded for reconsideration in light of Alabama Supreme Court guidelines, 526 S2d 634 (Ala 1987), illustrates the danger that Batson may not change very much. The case also offers further instruction to the prosecutor who seeks to evade Batson's requirements:

In Branch $v$ State, the prosecutors at the trial of a black defendant charged with murder used six of their seven peremptory challenges to strike six of the seven blacks on the venire. At a hearing challenging the use of the peremptories, the prosecution offered nonracial explanations for each of the six challenges. One juror was challenged because he was a scientist and it was feared that his background would put too much pressure on the prosecution. A second juror was challenged because he was similar in age and appearance to the defendant and he might have had a relationship to a person arrested in an unrelated criminal case several months earlier. The third juror was 


\section{Remedying Improper Exclusion}

Once a defendant establishes a prima facie case of discrimination, the prosecutor apparently must explain all prior and all subsequent strikes of prospective black jurors. A court that finds any of the prosecutor's explanations inadequate confronts a difficult issue of remedy. The Supreme Court said in Batson that it would "express no view on whether it is more appropriate ... for the trial court to discharge the venire and select a new jury from a panel not previously associated with the case ... or to disallow the discriminatory challenges and resume selection with the improperly challenged jurors reinstated on the venire . . . ."97 Neither alternative seems satisfactory.

A person excluded from a jury on grounds of race may not have harbored any bias against the state before his or her exclusion. Following this exclusion, however, the potential juror may be far from favorably disposed to the prosecutor. ${ }^{98}$ The restoration to a jury of one or more victims of a prosecutor's discrimination may deprive the public as well as the prosecutor of trial by an impartial

struck because she had been unemployed and had a kind of "dumbfounded or bewildered look on her face" as if uncertain about what she was supposed to do. The fourth juror was struck because she was a single female about the same age as the defendant and it was feared that she "might feel as though she were a sister . . . and have some pity on the [defendant]." The fifth juror was struck because it was the prosecutor's general experience that employees of the company where the juror worked had not been attentive as jurors and some employees at the company were being investigated for a variety of crimes. Finally, the sixth juror was struck because he was unkempt in appearance and gruff in manner, which might place him at odds with other jurors. The trial court found that the prosecution's reasons for its strikes were neutral and legitimate, and the appellate court affirmed, concluding that the trial court followed Batson "with caution and sensitivity."

Pizzi, 1987 S Ct Rev at 136 (footnotes omitted) (cited in note 66).

In State v Jackson, 322 NC 251, 368 SE2d 838, 839 (1988), a prosecutor used four of her five peremptory challenges to exclude blacks from a jury. She explained that one excluded juror was unemployed, had been a student counselor at Shaw University, and therefore had too "liberal a background"; that a second was a law student at the University of North Carolina and had been taught by professors of "somewhat liberal views"; that a third had a son about the same age as the defendant; and that a fourth was unemployed and "appeared indifferent and hostile." Id at 839,841 . On appeal, the defense attorney apparently did not object to the prosecution's exclusion of the law student who had been taught by liberal professors but did object to the other three exclusions. Although the prosecutor had failed to challenged unemployed whites, the court held that her explanations reflected "legitimate criteria in picking a jury." 368 SE2d at 841.

"27 476 US at $100 \mathrm{n} 24$.

28 Although neither the prosecutor's explanation for the prospective juror's exclusion nor the court's ruling that this explanation was inadequate might have occurred within the hearing of the juror, a person excluded from a jury and then restored might well infer the situation. 
tribunal. This remedy also could create a difficult interpersonal situation for the juror, the prosecutor, and others in the courtroom.

Moreover, this remedy would be burdensome and costly. Following a person's exclusion from a jury, he or she ordinarily may begin service as a juror in another case or go home. The defendant's prima facie showing of discrimination and the court's consideration of the adequacy of the prosecutor's reasons could follow this juror's exclusion by a few hours, a few days, or conceivably longer. A court might require every excluded juror of the same race as the defendant to remain available in the courthouse throughout the jury selection process on the chance that the prosecutor might exceed his or her quota of "free shots" or say something ugly; but this procedure obviously would be wasteful.

In light of the difficulties posed by efforts to restore improperly excluded jurors to a jury, the courts that have spoken to the issue have chosen the alternative remedy mentioned in Batson, dismissing the entire jury panel. ${ }^{99}$ Starting the jury selection process over, however, is costly to the public and the defendant. Moreover, this remedy may not always provide a strong incentive to refrain from discrimination. Indeed, in some situations, the remedy might give the prosecutor a broader de facto peremptory challenge than any provided by law. A prosecutor dissatisfied with an initial panel of prospective jurors-perhaps because this panel contained an unusual number of minorities-might seek to reduce the presence of minorities through the exercise of peremptory strikes. Were these strikes upheld, the prosecutor would gain a victory; and were they declared unlawful and the jury selection process begun anew, the prosecutor might regard this defeat as a greater victory still.

The prosecutor would have gained not only the exclusion of the prospective jurors whom he or she wrongfully challenged but also the exclusion of all other members of the panel. The prosecutor would in effect have been afforded a power to strike the entire panel peremptorily. A remedy that would give a prosecutor this power seems troublesome, however unlikely it is that many prosecutors would use it in so calculated a fashion. Both dismissing the entire panel and reinstating excluded jurors are unsatisfactory remedies. Abolishing the peremptory challenge and requiring a prosecutor to present, outside the hearing of prospective jurors,

${ }^{99}$ See People $v$ Wheeler, 22 Cal 3d 258, 282, 148 Cal Rptr 890, 906 (1978); State v Gilmore, 103 NJ 508, 539, 511 A2d 1150, 1167 (1986); Riley v State, 496 A2d 997, 1013 (Del 1985). 
cause for every exclusion before it occurred would make the choice between these remedies unnecessary.

D. Another License for Discrimination: The Substantial Representation of a Targeted Group on a Jury Even After Members of this Group Have Been Excluded

A recent Missouri decision, ${ }^{100}$ like an earlier ruling by the Second Circuit, ${ }^{101}$ severely limited the ability of some defendants to secure a remedy for discrimination in the jury selection process. In the Missouri case, the prosecutor used all of her peremptory challenges to strike six prospective black jurors and one prospective black alternate juror. Five blacks nevertheless escaped the net and served on the jury that tried the defendant. Because the defendant had been tried by a jury that included a substantial number of members of his race, the court concluded that he had not been "prejudiced" and lacked "standing to raise a Batson challenge."102

When nondiscriminatory jury selection yields a jury in which members of a defendant's race are under-represented or unrepresented, nothing in the Constitution entitles the defendant to relief. ${ }^{103}$ Declaring that the Constitution gives defendants no more than the luck of the draw when luck goes against them but that they are not entitled to colorblind luck when it would work in their favor does not reflect the coherent application of any constitutional principle. The Missouri court apparently would require justification for a prosecutor's peremptory exclusions only when the prosecutor exceeded his or her quota of "free shots" and also brought the number of minority jurors below the number that a system of proportional representation would have yielded. So long

${ }^{100}$ State $v$ Vincent, 755 SW2d 400 (Mo App 1988).

101 Roman v Abrams, 822 F2d 214, 229 (2d Cir 1987) (relying on a pre-Batson interpretation of the Sixth Amendment).

${ }^{102}$ Vincent, 755 SW2d at 403. Similarly, in Roman, the Second Circuit concluded that a prosecutor had offered only pretextual reasons for using peremptory challenges to remove eight members of the defendant's race from a jury panel, leaving only three members of this race on the jury. The court nevertheless denied relief, noting that the prosecutor's strikes had not "reduce[d] the petit jury representatives of [the defendant's race] dramatically below the group's percentage in the venire or in the population of the community." 822 F2d at 229.

${ }^{103}$ See, for example, Virginia $v$ Rives, 100 US 313, 322-23 (1880), overruled on other grounds, Greenwood v Peacock, 384 US 808 (1966); Apodaca v Oregon, 406 US 404, 413 (1972). But see Sheri Lynn Johnson, Black Innocence and the White Jury, 83 Mich L Rev 1611, 1695-1708 (1985) (arguing that a black, Native American, or Hispanic defendant should have a right to the inclusion of "racially similar" jurors on the tribunal that tries him or her). 
as the "bottom line" satisfied the court, there might be no limit on the prosecutor's power to discriminate.

\section{E. Discrimination on Nonracial Bases}

The prosecutor in a recent Fourth Circuit case offered his reasons for striking three prospective black jurors. Protesting that he had not struck these jurors because they were black, he insisted that he had eliminated them because they were women. ${ }^{104}$

The Supreme Court said in Batson that to establish a prima facie case of discrimination a defendant "must show that he is a member of a cognizable racial group ... and that the prosecutor has exercised peremptory challenges to remove from the venire members of the defendant's race." ${ }^{105}$ This statement and other references to race in the Batson opinion do not resolve the legality of peremptory challenges based on a prospective juror's gender. Issues of nonracial exclusion were not before the Court, and the Court did not address them. Nevertheless, the Fourth Circuit rejected the defendant's argument "that the Equal Protection Clause compels us to extend Batson to peremptory challenges exercised on the basis of gender." Court has announced its view that "Batson does not extend to gender-based discrimination."107

104 United States $v$ Hamilton, 850 F2d 1038 (4th $\mathrm{Cir} 1988$ ). The defendants in this case were nine black men and five black women, and the government used seven of its eight peremptory challenges to strike prospective black jurors. In explaining the exclusion of three of these jurors, the prosecutor declared that he wanted more men on the jury because he feared that the jury otherwise would be overly sympathetic to the women defendants. At the time that the prosecutor challenged the three black women, only one man had been seated.

105476 US at 96.

${ }^{108}$ Hamilton, $850 \mathrm{~F} 2 \mathrm{~d}$ at 1042.

${ }_{107}$ State v Oliviera, 534 A2d 867, 870 (RI 1987). But see State v Gilmore, 103 NJ 508, 511 A2d 1150, 1159 n 3 (1986) (holding that the New Jersey Constitution precludes the exercise of peremptory challenges on the basis of religious principles, race, color, ancestry, national origin, sex, and possibly other grounds). Decisions like those described in text reflect a mechanistic jurisprudence that has become increasingly common as the Supreme Court has drafted its judicial opinions as though they were legislative codes. See my paper, Personal Failure, Institutional Failure, and the Sixth Amendment, 14 NYU Rev L \& Soc Change 149, 154 \& n 15 (1986). A litigant asserting unconstitutional gender discrimination in the jury selection process is entitled to a principled resolution of this claim. Because no issue of gender discrimination was presented in Batson and because the Supreme Court did not discuss the merits of this issue even in dictum, the burden of providing a reasoned consideration of the litigant's claim must fall initially upon lower courts. When these courts do not assess the claim on its merits but instead parse the Supreme Court's opinion to determine what the Court "intended," they abdicate a central judicial responsibility. The fault lies both with a Supreme Court that appears to resolve by phrase and fiat issues not 
Courts have disagreed about the applicability of Batson to claims of discrimination against Italian-Americans, ${ }^{108}$ and the application of Batson to one form of racial discrimination also may prove problematic. Ruling that a pre-Batson decision limiting the discriminatory exercise of peremptory challenges precluded the systematic exclusion of whites as well as of blacks, the Second Circuit rejected a district court decision to the contrary. ${ }^{108}$

Justice Rehnquist once wrote that classifications based on national origin, "the first cousin of race," are presumptively invalid. ${ }^{110}$ In a nation settled in part by refugees from religious discrimination, classifications based on religious belief and affiliation may be suspect as well. Nevertheless, prosecutors commonly do classify on the basis of national origin and religion. In some jurisdictions, a person named Batsakis or Cohen is unlikely to sit on a jury that tries a Greek-American or Jew; and prosecutors regard religious affiliation as an important predictor of a juror's performance in drunk driving cases, other cases involving alcohol use, abortion-related cases, obscenity cases, asylum cases, and cases involving clerics. The Supreme Court has concluded that classifications based on race require "strict" scrutiny, and classifications based on national origin and religious affiliation may require strict scrutiny as well. Nevertheless, the Court has concluded that classifications based on gender require only intermediate scrutiny. ${ }^{111}$ Whether some nonracial forms of discrimination are as invidious as racial discrimination remains a subject of dispute. Nevertheless, in

before it and with lower courts that view the Court's nonjudicial style of adjudication as appropriate. Rather than attribute an unconstitutional assertion of power to the Supreme Court, see US Const, Art III, $\S 2$, lower courts should recognize their obligation to provide an unbiased judicial resolution of claims that have not previously been considered and resolved on their merits.

${ }^{108}$ Compare United States v Sgro, 816 F2d 30, 33 (1st Cir 1987), cert denied, 108 S Ct 1021 (1988) ("the defendant first must show that he is a member of a cognizable racial group"-assuming but not deciding that "the principles of Batson . . . extend to ethnic as well as racial constituencies," the record contains no evidence that Italian-Americans qualify as a cognizable group), with United States v Biaggi, 673 F Supp 96, 101 (E D NY 1987), aff'd, 853 F2d 89 (2d Cir 1988) ("The court takes judicial notice that Italian-Americans are considered in this district to be a recognizable and distinct ethnic group . ...").

${ }^{109}$ Roman $v$ Abrams, 822 F2d 214, 227-28 (2d Cir 1987). The court, however, upheld the defendant's conviction because his racial group was not "significantly underrepresented." Id at 229. See notes 101-02.

"10 Trimble $v$ Gordon, 430 US 762, 777, 780 (1977) (Rehnquist dissenting).

${ }^{112}$ Craig $v$ Boren, 429 US 190, 197 (1976) ("classification by gender must serve important governmental objectives and must be substantially related to achievement of those objectives"). Prosecutors (and defense attorneys) frequently exercise their peremptory challenges on the basis of gender in sexual assault cases, "battered-wife syndrome" cases, other domestic violence cases, abortion-related cases, child-victim cases, and others. See note 113. 
determining what restraints the Equal Protection Clause imposes on the jury selection process, the issue is not whether discrimination on the basis of gender, religion, ethnicity, national origin, political affiliation, or the like is "as bad as" racial discrimination. It is simply whether this discrimination is "bad."112 Once courts have recognized that the Equal Protection Clause limits the use of peremptory challenges for trial-related reasons, challenges justified only by a prosecutor's judgment that "I don't want women on a jury because I can't trust them"113 should be intolerable.

112 See Ballard v United States, 329 US 187, 193 (1946) ("Jury competence is an individual rather than a group or class matter. That fact lies at the very heart of the jury system. To disregard it is to open the door to class distinctions and discriminations which are abhorrent to the democratic ideals of trial by jury.") (quoting Thiel $v$ Southern Pacific Co, 328 US 217,220 (1946)).

113 See the material described in text at note 199. Practice manuals sometimes exhibit their authors' unabashed misogyny. Consider Melvin Belli's discussion of "women jurors":

This male author is reporting solely from his experience in the courtroom and, therefore, makes no apology for a presumptuousness when he reports that generally a male juror is more sound than a woman juror. . . . If counsel is depending upon a clearly applicable rule of law and if he wants to avoid a verdict of "intuition" or "sympathy," if his verdict in amount is to be proved by clearly demonstrated blackboard figures for example, generally he would want a male juror. . . .

....

If the plaintiff is a woman and has those qualities which other women envy-good looks, a handsome husband, wealth, social position-then women jurors would be unwise. Woman's inhumanity to women is unequalled. They are the severest judges of their own sex. ...

...

Women ... are desired jurors when plaintiff is a man. A woman juror may see a man impeached from the beginning of the case to the end, but there is at least the chance with the woman juror (particularly if the man happens to be handsome or appealing) that the plaintiff's derelictions in and out of court will be overlooked. A woman is inclined to forgive sin in the opposite sex; but definitely not in her own. ...

....

Women jurors tend to be more acutely opinionated and come to a quicker (sometimes unfortunately) decision than the male juror. ... Once a female juror makes up her mind (and as said above, this is usually done faster than with the male juror), even the most cogent of reasons rarely changes it.

Melvin M. Belli, Sr., 3 Modern Trials §§ 51.6-51.68 at 446-47 (West, 2d ed 1982). See also James W. Bouska, Selecting a Jury, in Patrick F. Healy and James P. Manak, eds, The Prosecutor's Deskbook 371, 373 (Natl Dist Attys Assoc, 1971) ("Women are said to be more responsive to emotional appeals and, at least from a male point of view, are more unpredictable and subject to being deterred from properly voting for conviction by other irrelevant factors ('I can't believe he'd steal anything. He looks like such a nice boy. Besides, there was no evidence he ever stole anything else.') . . . .); John Alan Appleman, Preparation and Trial 163 (Coiner, 1967) ("Ordinarily I don't want the argumentative female, or the barber, who becomes the great dissenter in the jury room."); James J. Doherty, "Ready for Trial, Your Honor" (Midwest, 1972) ("Regardless of the background of the individual female, she will be harsher in her judgment of the complaining witness [in a rape case] than a male juror."). 
Were Batson limited to cases of racial discrimination, the limitation would be unattractive. Nevertheless, if Batson were extended to discrimination grounded on "things like race" as well as race itself, there might be little left of the peremptory challenge. ${ }^{114}$

F. A Defendant's Standing to Object to Discrimination Against Prospective Jurors of a Race Other Than His or Her Own

In Peters $v$ Kiff, ${ }^{115}$ the Supreme Court set aside the conviction of a white defendant on the ground that blacks had been unlawfully excluded from the grand jury that indicted him. Some Justices found authority for this decision in the Due Process Clause of the Fourteenth Amendment; ${ }^{116}$ others, in a federal statute precluding racial discrimination in the selection of state grand juries. ${ }^{117}$

Similarly, the Court held in Taylor $v$ Louisiana ${ }^{118}$ that a man could challenge the unlawful exemption of women from a panel of prospective jurors. The Court grounded this ruling on the Sixth Amendment right to trial by an impartial jury, which it said guaranteed a defendant the right to "selection of a petit jury from a representative cross section of the community."

Like the defendant in Taylor, the defendant in Batson argued that the government's discrimination violated his Sixth Amendment right to trial by an impartial jury. In an effort to avoid a direct confrontation with Swain $v$ Alabama, the defendant expressly disclaimed reliance on the Equal Protection Clause. ${ }^{120}$ The Batson Court nevertheless overruled Swain, held that the Equal Protection Clause forbids a prosecutor's racially discriminatory use of peremptory challenges, and rejected the protests of dissenting Justices that no question under the Equal Protection Clause was before it. ${ }^{121}$

Although the Court explained why it thought that reliance on the Equal Protection Clause was permissible, ${ }^{122}$ it did not explain

\footnotetext{
114 See text at notes $180-99$.

115407 US 493 (1972).

118 Id at 494 (Marshall).

117 Id at 505 (White concurring.)

118419 US 522 (1975).

119 Id at 528.

120 The Supreme Court had rejected an equal protection challenge to the exemption of women from jury service in Hoyt $v$ Florida, 368 US 57 (1961). By relying on the Sixth Amendment rather than the Equal Protection Clause in Taylor, the Court avoided a direct overruling of this earlier decision. Id at 534. The defense attorney in Batson urged the Court to dance the same doctrinal sidestep.

${ }^{121}$ See 476 US at 115 (Burger dissenting) and 134 (Rehnquist dissenting).

122 Id at 84-85 n 4; see also id at 108-11 (Stevens concurring).
} 
why relying on this clause was preferable to accepting the ground of decision that the defendant had advanced (a ground that was in some ways more cautious ${ }^{123}$ ). For reasons that appeared mysterious, the Court rested its decision on the Equal Protection Clause rather than on the Sixth Amendment and, indeed, went to unusual lengths to do so.

Some observers have suggested that the fair-cross-section requirement of the Sixth Amendment differs from the Fourteenth Amendment's requirement of equal protection because it does not demand a showing of discriminatory purpose. ${ }^{124}$ Despite its label, however, the fair-cross-section requirement does not require a fair cross section, and proof of discriminatory effect does not establish a violation of this requirement. The Supreme Court has said that the fair-cross-section requirement forbids only the "systematic" exclusion of distinctive groups from jury service, ${ }^{125}$ and if any difference between "systematic" exclusion and "purposeful" exclusion exists, it is subtle. ${ }^{126}$ Neither concept appears to encompass "acci-

${ }^{123}$ Not only might reliance on the Sixth Amendment have made it unnecessary for the Court to overrule Swain, but this reliance might have enabled the Court to confine Batson to criminal cases. Unlike the Sixth Amendment, which applies only to criminal proceedings, the Equal Protection Clause apparently precludes discrimination by government lawyers in civil and criminal cases alike. The Batson decision's applicability to civil proceedings, however, like other troublesome issues posed by this decision, is certain to occupy the courts' attention and consume their resources. See Clark $v$ City of Bridgeport, 645 F Supp 890, 89496 (D Conn 1986) (applying Batson to jury selection by a government lawyer in a civil case); Esposito $v$ Buonome, 642 F Supp 760, 761 (D Conn 1986) (refusing to apply Batson to jury selection in a civil case); Holley $v J \& S$ Sweeping Co., 143 Cal App 3d 588, 592-93, 192 Cal Rptr 74 (1983) (applying a California decision similar to Batson to jury selection in civil cases); Terrio v McDonough, 16 Mass App 163, 450 NE2d 190, 196 (1983) (indicating without deciding that the court might apply a Massachusetts decision similar to Batson to jury selection in civil cases); Fleming $v$ Moore, 479 US 890 (1986) (denying certiorari in a case in which the petitioner sought to raise this issue-see 55 USLW 3100 (Aug 12, 1986)); Note, Batson v. Kentucky: Challenging the Use of the Peremptory Challenge, $15 \mathrm{Am} J$ Crim L 263, 300-01 (1988) (arguing that Batson does not preclude the discriminatory use of peremptory challenges in civil cases); Pizzi, $1987 \mathrm{~S} \mathrm{Ct}$ Rev at 119 (cited in note 66) (arguing that Batson is "fully applicable" to the government's use of peremptory challenges in some civil cases); Note, The Civil Implications of Batson v. Kentucky and State v. Gilmore: A Further Look at Limitations on the Peremptory Challenge, 40 Rutgers L Rev 891, 966 (1988) (arguing that Batson extends to civil cases).

124 See, for example, Wayne R. LaFave and Jerold H. Israel, Criminal Procedure § 21.2(c) at $711 \mathrm{n} 30$ (West, 1984). As LaFave and Israel observed, three dissenting Justices in Casteneda v Partida, 430 US 482, 510 (1977) (Powell dissenting), indicated that the faircross-section requirement might invalidate some practices not condemned by the Equal Protection Clause.

125 See, for example, Taylor v Louisiana, 419 US 522, 538 (1975); Duren v Missouri, 439 US 357, 364 (1979); Lockhart $v$ McCree, 476 US 162, 174 (1986).

${ }^{128}$ Perhaps "systematic" exclusion includes "knowing" as well as "purposeful" exclusion. For example, the voting scheme upheld in City of Mobile $v$ Bolden, 446 US 55 (1980), 
dental" exclusion (however frequently it may occur), and random selection appears to satisfy both Sixth and Fourteenth Amendment requirements. ${ }^{127}$ By substituting nearly identical doctrines for one another in an effort to dismiss prior decisions, lawyers, courts, and commentators have played a baffling numbers game. ${ }^{128}$ Chief Justice Burger's dissenting opinion in Batson may have offered a hint of one reason for the majority's doctrinal grounding of the case. A pre-Peters, pre-Taylor decision had suggested in dictum that the exemption of women from jury service would not vio-

was not intended to disadvantage blacks at its inception; but as a result of shifting housing patterns, it later had a disadvantageous effect. This voting scheme might have been said to disadvantage blacks "systematically" but not "purposefully."

${ }^{127}$ For example, were the luck of the draw to yield a jury, a jury panel, or even five consecutive jury panels composed entirely of wealthy Republican women golfers, their selection probably would not violate the Constitution. In every case in which the Supreme Court has found a violation of the fair-cross-section requirement, the differential treatment of a distinctive group was in fact purposeful.

${ }^{128}$ In Teague $v$ Lane, 44 Crim L Rptr (US 1989), the Supreme Court failed to resolve the claim of a habeas corpus petitioner that the fair-cross-section requirement precludes a prosecutor's discriminatory exercise of peremptory challenges. The Court held that a favorable resolution of this claim would not benefit the petitioner, for this ruling would not be applied retrospectively to a petitioner whose conviction was final at the time of the Court's decision. Noting its prior statements that "[f]airness in [jury] selection has never been held to require proportional representation of races on a jury," the Court declared, "[A]pplication of the fair cross section requirement to the petit jury would be a new rule." 44. Crim L Rptr at 3133.

The Court's characterization of the petitioner's fair-cross-section claim as "requiring 'fair and reasonable' proportional representation on the petit jury" was remarkable. See id at $3133 \mathrm{n} 1$. The Court recognized that the petitioner had expressly disavowed this claim. The Court nevertheless concluded that the petitioner had implicitly advanced the disavowed claim when he invoked the standard of Duren v Missouri, 439 US 357, 364-66 (1979). The Court had said in Duren, however, that the proportional underrepresentation of a group would violate the fair-cross-section requirement only if this underrepresentation were "due to systematic exclusion ... in the jury seclection process." 439 US at 364. Under Duren, the proportional underrepresentation of a distinctive group was necessary but insufficient to establish a violation of the fair-cross-section requirement.

Justice Brennan wrote in dissent in Teague $v$ Lane:

Teague's claim is . . closely akin to that which prevailed in Batson v. Kentucky ... where we held that the Equal Protection Clause forbids the prosecution from using its peremptory challenges to exclude venirepersons from the jury solely because they share the defendant's race. The only potentially significant difference is that Teague's claim, if valid, would bar the prosecution from excluding venirepersons from the petit jury on account of their membership in some cognizable group, whereas the Equal Protection Clause might not provide a basis for relief unless the defendant himself belonged to a group whose members were improperly excluded.

44 Crim L Rptr at 3144.

By treating the fair-cross-section claim in Teague as an open question, the Supreme Court may have signalled a retreat from what appeared to be its alternative holding in Lockhart $v$ McCree, 476 US 162, 174 (1986), that the fair-cross-section requirement does not extend to petit juries. 
late a male defendant's right to equal protection of the laws. ${ }^{128} \mathrm{Cit}$ ing this decision, Chief Justice Burger said that although discrimination on the basis of race, sex, religious or political affiliation and the like might violate the Equal Protection Clause, "a defendant would have to establish standing to raise [the issue] before obtaining any relief."130

The majority in Batson also may have indicated that its reliance on the Equal Protection Clause was designed to circumvent the concepts of standing articulated in Peters and Taylor. By invoking a constitutional provision not involved in those cases, the Court may have sought to wave a wand and cause the holdings of these cases to disappear. The Court intimated this objective in the same sentence that foretold its possible limitation of Batson to cases of racial discrimination: "To establish [a prima facie case of discrimination], the defendant first must show that he is a member of a cognizable racial group ... and that the prosecutor has exercised peremptory challenges to remove from the venire members of the defendant's race."131

Indeed, the Court appeared oblivious to the possibility that

128 Alexander $v$ Louisiana, 405 US 625, 633 (1972).

130476 US at 124 n 4 . See also Hobby v United States, 468 US 339, 347 (1984). LaFave and Israel have asserted without qualification that "under . . . the equal protection approach, the constitutional challenge can be made only by a defendant who is a member of the excluded class ...." Noting an Eleventh Circuit case that had permitted a Hispanic man to present an equal protection challenge to the exclusion of blacks and women from a grand jury, United States v Perez-Hernandez, 672 F2d 1380 (11th Cir 1982), the authors have suggested that "confusion on this point is to be found in some lower court cases." LaFave and Israel, Criminal Procedure $\S 21.2$ (c) at 709 and n 17 (cited in note 121). Some confusion on this point is also to be found in the LaFave and Israel treatise, however. The Supreme Court has not decided the issue, and only vague dicta in Supreme Court opinions even hint that "the constitutional challenge can be made only by a defendant who is a member of the excluded class." Decisions that members of an excluded class may challenge the exclusion of members of this class under the Equal Protection Clause do not justify the conclusion that other defendants may not. This article will suggest that in some circumstances the rationale of Strauder $v$ West Virginia, 100 US 303 (1880), entitles a defendant who is not a member of an excluded class to challenge a prosecutorial exclusion under the Equal Protection Clause. See text at notes 137-48.

${ }^{131} 476$ US at 96 (emphasis added). Possibly to ensure that defendants would not have the benefit of its Sixth Amendment rulings on standing when prosecutors discriminated against jurors whose races did not match theirs, the Court apparently ruled one week after Batson that the Sixth Amendment's fair-cross-section requirement extends only to the panels from which juries are selected, not to the juries themselves. Lockhart $v$ McCree, 476 US 162,174 (1986). This ruling was so unjustified and so unnecessary to resolution of the case before the Court that one may suspect an ulterior purpose. See my article, Failed Pragmatism: Reflections on the Burger Court, 100 Harv L Rev 1436, 1447-48 (1987). In Teague v Lane, 44 Crim L Rptr 3129 (US 1989), however, the Court may have retreated from Lockhart $v \mathrm{McCree}$ by treating the applicability of the fair-cross-section requirement to petit juries as an open issue. See note 128. 
prosecutors might systematically exclude blacks in cases involving white, Hispanic, Asian and Native-American defendants. The Batson opinion spoke repeatedly of the danger that a prosecutor would "challenge[] jurors of the defendant's race on the assumption ... that they would be partial to the defendant because of their shared race."132 It ignored other tactical goals that might prompt racially based exclusions. In a dissenting opinion, Justice Rehnquist voiced a similarly narrow view of the tactical objectives of prosecutors:

In my view, there is simply nothing 'unequal' about the State's using its peremptory challenges to strike blacks from the jury in cases involving black defendants, so long as such challenges are also used to exclude whites in cases involving white defendants, Hispanics in cases involving Hispanic defendants, Asians in cases involving Asian defendants, and so on. ${ }^{133}$

The empirical assumption apparently voiced by the majority and Justice Rehnquist, like much of the analysis in Batson, seemed either naive or disingenuous. Prosecutors sometimes do exclude the members of racial and other groups because they fear what psychologists call "in-group bias"-the tendency of members of a group to evaluate the actions of other members of that group favorably. ${ }^{134}$ Perhaps more fundamentally, however, prosecutors rank prospective jurors on what psychologists call an "authoritarianism scale." Criminal practitioners claim that the more "authoritarian" a juror is, the more likely he or she is to be a "good juror for the state." Moreover, just as courthouse folklore declares that men are more authoritarian than women, Christians (especially fundamentalist Protestants) more authoritarian than Jews, and Northern Europeans more authoritarian than Southern Europeans, it proclaims that whites are more authoritarian than blacks. The last stereotype may in fact be more powerful than the others. Innumerable "practice manuals" reveal that prosecutors-at least those who accept the conventional cluckings of courthouse corridors-seek to avoid minority jurors whatever the race of the defendant. ${ }^{135}$

132476 US at 97.

15s Id at 137-38 (Rehnquist dissenting).

134 See Pizzi, 1987 S Ct Rev at 129-30 (cited in note 66).

1s5 See, for example, John M. VanDyke, Jury Selection Procedures 153 (Ballinger, 1977); Irving Goldstein and Fred Lane, 1 Trial Technique $\$$ 9.45, 9.48 (Callaghan, 3d ed 1984). I understand, however, that in some prosecutorial circles older black women are re- 
In a concurring opinion in Batson, Justice Marshall presented evidence that should have shaken the apparent premises of the majority and Justice Rehnquist. He noted: "In 100 felony trials in Dallas County in 1983-1984, prosecutors peremptorily struck 405 of 467 eligible black jurors; the chance of a qualified black sitting on a jury was 1 in 10, compared to 1 in 2 for a white." ${ }^{\text {"136 }}$ Prosecutors did not accomplish this disenfranchisement of a race by striking blacks only in cases involving black defendants.

Although the Supreme Court's language suggests that it might not permit non-black defendants to challenge the discriminatory exclusion of blacks from their juries, the Court offered no justification for this possible restriction. ${ }^{137}$ In 1880 , the Court held in the landmark case of Strauder $v$ West Virginia ${ }^{138}$ that the statutory exclusion of blacks from jury service violated a black defendant's right to equal protection of the laws. The Court did not discuss at length why someone not protesting his or her own exclusion from a jury could challenge the West Virginia statute. The Court, however, noted the social circumstances of the times:

[For the framers of the Fourteenth Amendment], it required little knowledge of human nature to anticipate that those who had long been regarded as an inferior and subject race would, when suddenly raised to the rank of citizenship, be looked upon with jealousy and positive dislike ....

It is well known that prejudices often exist against particular classes in the community, which sway the judgment of jurors, and which, therefore, operate in some cases to deny to persons of those classes the full enjoyment of that protection which others enjoy. ${ }^{139}$

In a related case, Justice Strong, the author of the opinion in Strauder, reiterated and clarified the basis of the Court's decision:

In [Strauder] we held that the Fourteenth Amendment secures, among other civil rights, to colored men, when

garded as "good jurors for the state." In addition, blacks who are employed and married and who have schoolage children are reputed to be "tough" in drug cases.

${ }^{136} 476$ US at 104 (citing Dallas Morning News 1 (March 9, 1986)).

${ }^{137}$ Of course the ability of a defendant to challenge the discriminatory exclusion of members of a race other than his or her own was not before the Court in Batson. The Court's language need not be read to refer to circumstances other than those presented in Batson itself. See note 107 .

${ }^{138} 100$ US 303 (1880).

139 Id at $306,309$. 
charged with criminal offences against a State, an impartial jury trial, by jurors indifferently selected or chosen without discrimination against such jurors because of their color. . . . We held that such an equal right to an impartial jury trial, and such an immunity from unfriendly discrimination, are placed by the amendment under the protection of the general government and guaranteed by it. ${ }^{140}$

The standing of the defendant in Strauder apparently did not rest on atmospheric notions of racial identity or racial solidarity;:141 it rested instead on the proposition that the citizens whom the government had arbitrarily excluded from jury service were more likely to favor the defendant's position than the citizens whom it had permitted to serve. In the Court's words, the defendant had been denied "an equal right to an impartial jury trial."142 In the social climate of 1880 , black jurors were more likely to favor the defendant's acquittal than white jurors.

Strauder allowed black defendants to challenge the statutory disqualification of blacks from jury service, and the Court's opinion offered a plausible (though no longer accepted ${ }^{143}$ ) basis for denying white defendants the same opportunity. If, in 1880 , white jurors were likely to be biased against black defendants but not against white defendants, the state's statutory disqualification of black jurors disadvantaged only black defendants. Apart from the people excluded from jury service, only black defendants qualified as victims of West Virginia's "unfriendly discrimination."144 This basis for differentiating black and white defendants disappears, however, when a prosecutor discriminates in the exercise of peremptory challenges. Unlike a statutory disqualification, the prosecutor's challenges are designed to disadvantage black and white defendants alike; both groups are victims of the prosecutor's "unfriendly

${ }^{140}$ Ex parte Virginia, 100 US 339,345 (1880). The Supreme Court's declaration that a discriminatory exclusion from jury service could impair a defendant's right to "an impartial jury trial" seems incompatible with the Court's statement more than 100 years later: "Any claim that the jury was not impartial . . . must focus not on [a potential juror who was excluded] but on the jurors who ultimately sat." Ross $v$ Oklahoma, 108 S Ct 2273, 2277 (1988).

141 Moreover, although the Supreme Court has hinted that a defendant's standing to present an equal protection challenge to the exclusion of members of his or her race from a jury rests on the proposition that he or she is stigmatized by the exclusion, see Hobby $v$ United States, 468 US 339, 347 (1984), the standing of the defendant in Strauder did not rest on the proposition that he had been stigmatized.

142 Ex Parte Virginia, 100 US at 345 (summarizing the holding in Strauder.)

14s See Peters v Kiff, 407 US 493 (1972); Taylor v Louisiana, 419 US 522 (1975).

14 Ex Parte Virginia, 100 US at 345. 


\section{discrimination."}

The exclusion of a prospective juror can deny the defendant "an equal right to an impartial jury trial" whether or not the race of the excluded juror matches the defendant's. A defendant's prospect of success at trial is in fact no more substantially reduced by a prosecutor's exclusion of members of his or her race from a jury than by the prosecutor's exclusion of members of other races; every exercise of a peremptory challenge by a prosecutor is designed to limit the likelihood of the defendant's success at trial. A defendant "injured in fact" by a prosecutor's discriminatory use of peremptory challenges lacks the opportunity to gain vindication at trial that a defendant whose jury has been selected without discrimination enjoys. Under Strauder, this defendant has been denied the equal protection of the laws and should be permitted to challenge the prosecutor's exclusion. . $^{145}$

The Strauder opinion might be read as "incorporating" the right to an impartial jury trial in the Equal Protection Clause of the Fourteenth Amendment eighty-eight years before the Supreme Court "incorporated" the same right in the Due Process Clause. ${ }^{146}$ Affording the right to an impartial jury trial to some defendants and not to others violates the equal protection principle, and standing under the Equal Protection Clause should therefore be determined by the same principles that determine standing under the Sixth Amendment.

To be sure, claims of equal protection might be pressed too far; proving that a prosecutor's lawful challenges reduced a defendant's chances of success at trial and that prosecutors in other cases have failed to make similar challenges would not establish an equal protection violation. The appropriate baseline is the one suggested by Strauder: defendants are entitled to an equal right to an impartial jury trial. Prosecutorial exclusions that make juries more impartial do not violate this right; unjustified prosecutorial exclusions do.

The Batson opinion, however, may have rejected the factual premises of Strauder. The Court condemned as constitutionally impermissible the view that black jurors will be "partial to the de-

145 This argument rests on the assumption that some juries are in fact lawfully selected; if they are, a defendant injured by a prosecutor's unlawful discrimination has been denied the same opportunity to obtain vindication at trial that a defendant tried by a properly selected jury enjoys. For this reason, the defendant has been denied equal protection whether or not he or she otherwise would have had standing to challenge the prosecutor's discrimination.

${ }^{146}$ See Duncan v Louisiana, 391 US 145 (1968). 
fendant because of their shared race." Nevertheless, on the premises of Batson, the standing of a defendant to challenge the exclusion of a juror whose race does not match his or hers seems clearer. If prosecutors may not act on the perception that black jurors are more likely than white jurors to acquit black defendants, the Supreme Court also should be precluded from acting on this perception. The Court could not fairly limit the standing of defendants on the basis of a perception that it regarded as racist when held by prosecutors. ${ }^{147}$ Under Strauder, a defendant may challenge any exclusion that denies him or her "an equal right to an impartial jury"; and unless a court can conclude that one exclusion infringes this right more substantially than another, the defendant must have standing either to challenge both exclusions or to challenge neither. ${ }^{148}$

Limiting the standing of defendants in the manner that Batson seems to contemplate would require courts to draw troublesome racial lines. If defendants were allowed to challenge the exclusion only of members of their own races, a defendant whose grandparents were black, Hispanic, Asian, and Native American apparently would be permitted to challenge the exclusion of mem-

${ }^{147}$ Of course, if white jurors as a group are no longer more likely than black jurors to convict black defendants, the factual basis of the decision in Strauder is unsound. Batson may suggest that the Supreme Court should overrule Strauder. Even were the Court to adopt this all but unthinkable position, however, it might permit defendants to challenge the discriminatory exercise of peremptory challenges by prosecutors. When a prosecutor has concluded that particular jurors are likely to favor a defendant, the defendant is more plainly "injured in fact" by the exclusion of these jurors than he would be by a broader, less refined statutory exclusion.

14 To reiterate in somewhat different language the analysis in text, one might conclude, as Strauder did, that black jurors are more likely to acquit black defendants than white jurors. This view, however, would not justify the different conclusion that black jurors challenged by a prosecutor are more likely to favor the defendant than white jurors challenged by the prosecutor. Every improper exclusion by a prosecutor reduces the defendant's chance of success at trial and makes conviction more likely than it would be if the defendant were tried by a properly constituted trial jury. Every unjustified exclusion therefore denies the defendant "an equal right to an impartial jury trial." Strauder provides no basis for permitting a defendant to challenge the peremptory exclusion of some prospective jurors but not others.

Alternatively, one might conclude, as the Batson Court did, that black jurors are no more likely to be "partial" to black defendants than white jurors (or, perhaps, that it is unconstitutional to act on the assumption that blacks and whites differ in their partiality toward black defendants whether this premise is accurate or not). On this view, one must reach the same conclusion at an earlier stage of analysis. Again there is no basis for treating the exclusion of black jurors and exclusion of white jurors differently-at least not when the issue is the one posed by Strauder, impairment of a defendant's "equal right to an impartial jury trial." 
bers of all of these groups. ${ }^{149} \mathrm{~A}$ defendant whose ancestry was less diverse would have less power to object to a prosecutor's racial discrimination. In determining precisely what ancestry would qualify a defendant as black, white, brown or red, courts might find guidance in some older decisions of states that practiced de jure segregation, in the opinions of South African tribunals, and in the precedents of Nazi Germany.

After determining the ancestry of defendants and prospective jurors, courts would confront issues of racial matching. A court might be required to decide, for example, whether a MexicanAmerican defendant could challenge the discriminatory exclusion of Puerto Rican jurors (or Castilian-American jurors) on the ground that the defendant and the jurors were Hispanic or whether instead the defendant and the jurors should be regarded as members of different groups. ${ }^{150}$

Although compelling reasons for classifying people on the basis of race sometimes may exist, concepts of standing resting on notions of "racial solidarity" do not advance compelling goals. Far from being mandated by Article III of the Constitution, these concepts require racial classifications that may violate the Equal Protection Clause. Declaring that inquiry into the racial and ethnic background of prospective jurors is "unseemly and intrusive," the Arizona Supreme Court has rejected the ungenerous hint of Batson and ruled that a white defendant may challenge the discriminatory exclusion of black prospective jurors. ${ }^{151}$

140 A court might conclude, however, that this defendant was a member of no distinctive "racial group" so that he or she would lack standing to challenge the discriminatory exclusion of anyone. Compare People v Seals, 153 Ill App 3d 417, 505 NE2d 1107, 1111 (1987) (allowing a defendant of racially mixed ancestry who had "the appearance of a black" to challenge the exclusion of black jurors).

${ }^{180}$ A court might rule in one case that Mexican-Americans and Puerto Ricans should be treated as members of the same ethnic group. It might rule in the next case, however, that, in light of the historic enmity between China and Japan and their lack of a common language, a Japanese-American defendant could not challenge the discriminatory exclusion of prospective Chinese-American jurors. One cringes at the prospect of turning constitutional rights on the invidious, irrelevant inquiries that Batson seems to contemplate.

${ }_{181}$ State $v$ Superior Court, 157 Ariz 541, 760 P2d 541, 544-45 (Ariz 1988) (relying on the Sixth Amendment rather than the Equal Protection Clause). See also State $v$ Gilmore, 103 NJ 508, 511 A2d 1150, 1164 and n 9 (1986) (relying on the New Jersey rather than the United States Constitution). But see United States v Townsley, 856 F2d 1189, 1190 (8th Cir 1988) (en banc) (Batson is "clear and straightforward" in denying standing to white defendants to challenge the exclusion of black prospective jurors); United States $v$ Vaccaro, 816 F2d 443, 457 (9th Cir 1987) (alternative holding); Torres v State, 44 Crim L Rptr 2409 (Fla App 1989) (a white defendant, even one represented by a black attorney, does not have standing to challenge the exclusion of black prospective jurors); People $v$ Holland, 121 Ill $2 \mathrm{~d}$ 136, $520 \mathrm{NE} 2 \mathrm{~d}$ 270, 279-80 (1987) (a white defendant lacks standing under Batson to pre- 
Although this article has argued that a prosecutor's discriminatory exclusion of jurors whose races differ from the defendant's can violate the defendant's Fourteenth Amendment rights, this issue may not be decisive. On occasion, the Supreme Court has permitted litigants to assert rights other than their own. Allowing defendants to assert the Fourteenth Amendment rights of excluded jurors would avoid the complexities of Strauder's hybrid concept of "an equal right to an impartial jury trial."

When prosecutors discriminate in the exercise of peremptory challenges, the rights they violate most clearly and directly are those of prospective jurors. The interests of these jurors include not only the opportunity to serve on juries (an opportunity that many of them would gladly decline) but also and more importantly their freedom from classification on invidious grounds. Indeed, as the Supreme Court noted in Batson, "The harm from discriminatory jury selection extends beyond that inflicted on the defendant and the excluded juror to touch the entire community."1152 Holding that the parties to a criminal case may assert the rights of improperly excluded jurors would permit defendants to challenge the exclusion of jurors of races other than their own. Moreover, this holding would permit prosecutors to challenge discrimination by defense attorneys-a result that the next section of this article will suggest could not occur if prosecutors were allowed to assert only the rights of the government.

The Supreme Court has observed:

Where practical obstacles prevent a party from asserting rights on behalf of itself, ... the Court has recognized the doctrine of jus tertii standing. In such a situation, the Court considers whether the third party has sufficient injury-in-fact to satisfy the Art. III case-or-controversy requirement, and whether, as a prudential matter, the third party can reasonably be expected properly to frame the issues and present them with the necessary adversarial zeal. ${ }^{153}$

A prospective juror subjected to unconstitutional discrimination by a prosecutor faces not only practical but legal obstacles to the vindication of his or her rights. This juror may be unaware that

sent an equal protection challenge to the exclusion of blacks, and the discriminatory exercise of peremptory challenges does not violate the Sixth Amendment's fair-cross-section requirement), cert granted, $109 \mathrm{~S} \mathrm{Ct} 1309$ (1989).

182476 US at 87.

${ }^{153}$ Secretary of State of Md. v J. H. Munson Co., 467 US 947, 956 (1984). 
any discrimination has occurred; and even if the juror recognizes or suspects that it has, he or she is almost certain to be unrepresented by counsel. Although an unusually assertive juror might demand a hearing on the propriety of his or her exclusion, the predictable judicial response would be one of rejection-probably one of astonished rejection. The court would reply that a juror may not interrupt an ongoing criminal proceeding to demand a hearing simply because the juror's own rights may have been violated. In accordance with customary practice, jurors should speak only when spoken to. ${ }^{154}$

Once a jury has been empaneled, the violation of an excluded juror's rights is complete, and no remedy can prevent the wrong. In the unlikely event that an excluded juror sought a remedy, moreover, he or she would fail. It plainly would be too late to secure a place on the jury through injunction or mandamus; and if the excluded juror attempted to prevent recurrence of the prosecutor's discrimination in a future case, the court would respond that the threat of repetition was remote and the pattern of unconstitutionality insufficiently established by a single act of discrimination. ${ }^{165}$ Were the excluded juror then to seek damages for the prosecutor's violation of his or her rights, the juror would discover that prosecutors are immune from liability for even deliberate abuse of their courtroom responsibilities. ${ }^{156}$ Whatever the chance that sufficiently repeated prosecutorial abuse might lead to injunctive relief in a class action-and it is not great-an individual wrongly excluded from a jury cannot secure any redress for the violation of his or her rights.

Although prospective jurors are legally as well as practically precluded from vindicating their rights, a criminal defendant suffers "injury in fact" from every unlawful exclusion by a prosecutor. (At least the prosecutor believes that the exclusion will diminish the defendant's prospect of success at trial.) Unlike the prospective juror, the defendant usually is represented by counsel and can seek to prevent the wrong rather than merely correct it. ${ }^{157}$ Moreover, the high stakes of criminal prosecutions encourage defendants to present claims of discrimination with "the necessary adversary zeal" and sometimes more. Were a court to reject a defendant's claim that unlawful discrimination by a prosecutor violated his or

\footnotetext{
164 See text at notes 34-37.

18s See, for example, Rizzo v Goode, 423 US 362 (1976).

${ }^{186}$ See Imbler $v$ Pachtman, 424 US 409 (1976).

167 See text at notes 97-100.
} 
her rights, the defendant nevertheless should have standing to assert the rights of excluded jurors. A defendant injured in fact by a prosecutor's unconstitutional exclusion presents a classic case of appropriate third party standing. This standing, moreover, is unaffected by whether the excluded juror is the same color as the defendant.

In Rose $v$ Mitchell, ${ }^{158}$ the Supreme Court reaffirmed its prior decisions that convicted defendants may demonstrate racial discrimination in the selection of grand juries and thereby secure habeas corpus relief even after their conviction by properly constituted trial juries. A finding of guilt beyond a reasonable doubt by a fairly chosen trial jury seems to establish probable cause to place a defendant on trial and more. Defects in the initial determination of probable cause can be seen, in retrospect, not to have affected substantial rights of the defendant. ${ }^{159}$ The Supreme Court nevertheless observed, "The exclusion from grand jury service of Negroes, or any group otherwise qualified to serve, impairs the confidence of the public in the administration of justice."160 Primarily for this reason, the Court concluded that proof of racial discrimination in the selection of a grand jury would entitle a prisoner to relief from his or her conviction "without inquiry into whether [he or she] was prejudiced in fact by the discrimination at the grand jury stage." $" 181$

When a prosecutor has discriminated in the exercise of peremptory challenges, the injury to excluded jurors and to the community is like that in Rose v Mitchell, but the injury to the defendant seems far less ephemeral. The concerns that led to the decision in Rose also should entitle a defendant to challenge any unlawful exclusion by a prosecutor-whether the target of this unlawful exclusion is a member of the defendant's race or some other.

\section{G. Racial Discrimination by Defense Attorneys}

In Miami in 1980, four white police officers were tried on charges that they had beaten to death a black man arrested for a traffic violation. The defendants' attorneys, acting together, struck

158443 US 545 (1979). See also Vasquez v Hillary, 474 US 254, 260-64 (1986) (reaffirming Rose and declaring that racial discrimination in the selection of a grand jury can never be treated as harmless error).

158 See Rose, 443 US at 574 (Stewart concurring); Cassell $v$ Texas, 339 US 282, 302 (1950) (Jackson dissenting).

${ }^{160}$ Rose, 443 US at 556.

161 Id. 
every potential black juror, and the all-white jury that their challenges produced acquitted the officers. The Miami riots followed.

Four years later, another Miami police officer was charged with manslaughter in the death of a black suspect. Again the defense attorney's strikes produced an all-white jury; again the defendant was acquitted; and again the acquittal sparked public outcry (this time, fortunately, nonviolent). ${ }^{\mathbf{1 6 2}}$

After the second controversial acquittal, the Florida Supreme Court ruled that racial discrimination in the selection of a trial jury by either the prosecution or the defense violates the Florida constitution. ${ }^{163}$ Discrimination by defense attorneys can undermine the democratic values of the jury system and subvert public confidence in the administration of justice as powerfully as racial discrimination by prosecutors. ${ }^{164}$

Confining its language to the case before it for a change, the Supreme Court said in Batson, "We express no views on whether the Constitution imposes any limit on the exercise of peremptory challenges by defense counsel."160 Chief Justice Burger, writing in dissent, appeared skeptical of the Court's reservation of the issue:

[T] he clear and inescapable import of this novel holding will inevitably be to limit the use of this valuable tool to both prosecutors and defense attorneys alike. Once the Court has held that prosecutors are limited in their use of peremptory challenges, could we rationally hold that defendants are not? "Our criminal justice system 'requires not only freedom from any bias against the accused, but also from any prejudice against his prosecution. Between him and the state the scales are to be evenly held." "166

${ }^{162}$ See Pizzi, 1987 S Ct Rev at 153-54 (cited in note 66).

${ }^{163}$ Neil v State, 457 S2d 481, 486 (Fla 1984). Similarly, state courts in California and Massachusetts have condemned racial discrimination by prosecutors and defense attorneys alike. People v Wheeler, $22 \mathrm{Cal} 3 \mathrm{~d}$ 258, $148 \mathrm{Cal}$ Rptr 890 (1978); Commonwealth v Soares, 377 Mass 461, 387 NE2d 499, 516 (1979).

${ }^{184}$ In 1986, whites were reported to have committed 81,000 crimes against black victims. See Marcia Coyle, Can Bias by Defense Be Barred?, Natl L J 3, 30 (Nov 14, 1988).

${ }^{18 s} 476$ US at $89 \mathrm{n} 12$. Although Justice Marshall expressed disapproval of discrimination by defense attorneys, he did not argue that this discrimination was unconstitutional. Instead, he merely asserted that, if the Supreme Court were to abolish the use of peremptory challenges by prosecutors (as he argued that it should), a state legislature might constitutionally eliminate the use of peremptory challenges by defense attorneys. Id at 107-08 (Marshall concurring).

${ }^{186}$ Id at 125-26 (Burger dissenting) (quoting both the concurring opinion of Justice Marshall in Batson, id at 107, and Justice Marshall's quotation of Hayes $v$ Missouri, 120 US 68,70 (1887)) (footnote omitted) (emphasis in original). 
Contrary to Chief Justice Burger's apparent intimation, nothing in the Constitution entitles a state to balanced scales or even a fair trial in criminal cases. In accordance with its central objective-the control of governmental power-the Constitution generally creates rights against the government, not rights in favor of the government. ${ }^{167}$ At least in state courts, ${ }^{168}$ if the Constitution restricts the discriminatory use of peremptory challenges by defense attorneys, it does so only by guaranteeing prospective jurors the right to equal protection of the laws.

Discrimination by defense attorneys violates this right only if it qualifies as state action, ${ }^{\mathbf{1 6 9}}$ but a court should not hesitate to hold that it does. Jurors are paid public employees charged with important responsibilities, and defense attorneys discriminate in the selection of these officials only because state statutes and rules expressly delegate the power to select jurors to them. ${ }^{170}$ Moreover, when attorneys use this power, judges ratify their choices by formally discharging the prospective jurors whom the attorneys have disapproved. A state should not be permitted to delegate the power to determine the composition of official tribunals and then disclaim responsibility for the predictably discriminatory way in which this authority is exercised.

That defense attorneys act as "officers of the court" in selecting trial jurors is more than a metaphor, and a decision that in doing so they perform an inherently governmental task would not imply that their other functions are subject to constitutional restraint as well. ${ }^{171}$ Although this brief analysis does not exhaust the reasons for viewing the selection of trial jurors by lawyers as state

${ }^{187}$ For example, the Constitution forbids the government from depriving any person of life, liberty or property without due process of law. US Const, Amend V and Amend XIV. It does not forbid a person from depriving the government of life, liberty or property without due process of law. See Susan Bandes, Taking Some Rights Too Seriously: The State's Right to a Fair Trial, $60 \mathrm{~S}$ Cal L Rev 1019 (1987).

${ }^{168}$ Article III, § 2 of the United States Constitution provides that "the trial of all Crimes, except in Cases of Impeachment, shall be by Jury." This provision might plausibly be interpreted to afford the federal government a right to jury trial in criminal cases. But see Patton v United States, 281 US 276, 298 (1930) ("Article III, Section 2 . . was meant to confer a right upon the accused which he may forego at his election"). Plainly neither the Sixth nor the Fourteenth Amendment confers any right to jury trial upon state governments.

${ }^{182}$ See Civil Rights Cases, 109 US 3, 13 (1883).

170 See, for example, FRCrP 24(a); 11A NY CPL, § 270.15(2) (McKinney 1982).

${ }^{171}$ Compare Branti $v$ Finkel, 445 US 507, 519 (1980) (public defender acts under color of state law in hiring and firing state employees), with Polk County $v$ Dodson, 454 US 312, 318 (1981) (public defender does not act under color of state law in representing a client at trial simply because he or she holds a license from the state to practice law). 
action, ${ }^{172}$ courts should hold that the exercise of peremptory challenges by defendants and defense attorneys is subject to constitutional restraints.

A more substantial hurdle to controlling discrimination by defense attorneys is the restricted concept of standing that the Supreme Court intimated it might approve. Permitting prosecutors to resist all discriminatory challenges by defense attorneys would be unconscionable if defendants were unable to resist all discriminatory challenges by prosecutors. Were a defendant able to challenge only the unlawful exclusion of members of his or her race, the government, which is neither white nor black, apparently would lack standing to challenge the exclusion of anyone.

The Supreme Court's effort to impose only minimal restraints on the use of peremptory challenges by prosecutors may have been too clever. Eliminating the ability of defendants to challenge the exclusion of members of races other than their own would appear to eliminate altogether the ability of prosecutors to challenge discrimination by defense attorneys; prosecutors must have standing either to challenge all unlawful discrimination by defense attorneys or else to challenge none. Perhaps, in light of the Supreme Court's apparently restrictive view of standing, it should not have treated the power of defense attorneys to discriminate in the exercise of peremptory challenges as an open question.

When defense attorneys discriminate, the rights they violate are those of prospective jurors; and as noted above, these jurors are unable to vindicate their rights. Just as defendants should be permitted to act as surrogates for excluded jurors in challenging discrimination by prosecutors, prosecutors should be permitted to act as surrogates in challenging discrimination by defense attorneys. A conventional view of both the law of third party standing and the law of state action suggests that discrimination by defense attorneys should be limited in the same way and to the same extent that discrimination by prosecutors is restricted. Nevertheless, only a concept of third party standing that would empower defendants to challenge all unlawful discrimination by prosecutors could pro-

${ }^{172}$ See People v Gary M., 526 NYS2d 986, 994 (S Ct 1988) (holding after careful analysis of the issue that the discriminatory exercise of peremptory challenges by defense attorneys is impermissible state action); Note, Discrimination by the Defense: Peremptory Challenges After Batson v. Kentucky, 88 Colum L Rev 355, 358-61 (1988); Note, 40 Rutgers L Rev at 949-55 (cited in note 123). But see Holtzman v Supreme Court, Kings County, 526 NYS2d 892, 898 (S Ct 1988); Goldwasser, Limiting a Criminal Defendant's Use of Peremptory Challenges (cited in note 65); Note, Defendant's Discriminatory Use of the Peremptory Challenge after Batson v. Kentucky, 62 St John's L Rev 46 (1987). 
duce this reciprocal control. Chief Justice Burger may have been correct that "[b]etween [the accused] and the state the scales are to be evenly held," but there is only one legitimate way to achieve this balance under the Constitution.

H. The Unconstitutionality of the Peremptory Challenge: Is It Bedtime for Batson?

This article's review of seven areas of litigation created by Batson ${ }^{173}$ suggests that this decision will generate expensive and divisive courtroom proceedings for years or even decades to come. Like much of the Batson opinion, the Supreme Court's declaration, "Nor are we persuaded by the State's suggestion that our holding will create serious administrative difficulties,"174 seemed to reveal a limited understanding of the litigation process. In the brief period since Batson was decided, hundreds of reported appellate cases and a larger number of trial court hearings have confirmed William Pizzi's observation: "If one wanted to understand how the American trial system for criminal cases came to be the most expensive and time-consuming in the world, it would be difficult to find a better starting point than Batson."175 Batson has imposed heavy administrative costs for one apparent reason: The Supreme Court sought to manifest its symbolic opposition to racial discrimination while doing as little as possible to alter the peremptory challenge.

If the Batson decision notably reduces some forms of discrimination by prosecutors, it nevertheless will offer a lesson in hydraulics. Batson has moved discrimination from the intentions and unexplained practices of trial lawyers to the pages of appellate

${ }^{173}$ Eight areas if one counts the question of Batson's applicability to civil proceedings. See note at 123. Batson has spawned litigation concerning other issues as well. Notably, both the Sixth Circuit and the Seventh Circuit have ruled that when a defendant makes a prima facie showing of discrimination, a prosecutor may explain his or her reasons for striking prospective black jurors outside the presence of the defendant and the defendant's lawyer. United States v Davis, 809 F2d 1194, 1201 (6th Cir 1987), cert denied, 107 S Ct 3234 (1987); United States v Tucker, 836 F2d 334, 340 (7th Cir 1988). This procedure seems no more consistent with due process than the banishment of the plaintiff in a Title VII action during the defendant's presentation of his or her case. Two other federal Courts of Appeals have indicated that they might approve ex parte, in camera explanations by prosecutors in truly exceptional circumstances (for example, when an undercover investigation has revealed that a prospective juror is a drug dealer and the government does not wish to tip its hand); but these courts have declined to follow the more expansive Sixth and Seventh Circuit rulings. United States v Thompson, 827 F2d 1254, 1259 (9th Cir 1987); United States $v$ Garrison, 849 F2d 103, 106-07 (4th Cir 1988).

174476 US at 99.

173 Pizzi, 1987 S Ct Rev at 155 (cited in note 66). 
reports. Dark motives and tactics that formerly were unexpressed (however strongly their presence was suspected) have emerged into the light of judicial approval.

Batson has created a new legal institution, the "quasi-peremptory challenge." The peremptory challenge permitted courts to presume that prosecutors were acting for legitimate reasons even when they probably were not, but the quasi-peremptory challenge denies courts this indulgence. The Supreme Courts's new form of challenge requires explanation, although not justification or cause. When a prosecutor declares, "I struck this potential juror because she is handicapped and therefore might sympathize with someone's misfortune," a judge is likely to reply, "You did not strike her because she is black. That is good enough." More important than the economic costs of Batson are the invidious distinctions that it draws and invites.

When the dust settles (if it does), Batson may stand for the following propositions: ${ }^{176}$ (1) Although prosecutors may not discriminate against blacks, defense attorneys may. (2) Prosecutors may not discriminate against black jurors in cases with black defendants, but they may discriminate against black jurors in cases with white defendants. (3) For practical purposes, discrimination means taking more than one or two "shots" at prospective black jurors in a single case. A court need not conduct an inquiry until a prosecutor has made things look bad, so one or two "free shots" are permissible. (4) Prosecutors who wish to discriminate against more than one or two blacks in a single case must advance reasons for their challenges that appear racially neutral. (5) Nevertheless, because black defendants are entitled to no more than proportional representation of their race on a jury, prosecutors may exclude more than one or two blacks without giving reasons when an unusual number of blacks appear on the panel of prospective jurors. (6) Although prosecutors may not discriminate against blacks, they may discriminate against unemployed people, people who fail to maintain eye contact with prosecutors, people who stare at prosecutors, liberals, social workers, people who live in public housing, people who have not finished high school, and others who also happen to be black. (7) Similarly, prosecutors may discriminate

176 The description that follows does not indicate the inevitable end point of the litigation that Batson has engendered; but even if many courts ultimately reject some of the limitations that some courts now embrace, Batson will have imposed substantial administrative costs and engendered artificial and disturbing constitutional rulings for the sake of a limited gain. 
against women, Jews, Italian-Americans, homosexuals, and the handicapped. (8) When prosecutors discriminate in violation of these principles, the victims of their discrimination will be excluded from the jury (along with other prospective jurors) and the jury selection process begun anew.

Whether Batson marks a substantial victory in the struggle to abolish discrimination in the administration of criminal justice is debatable. As much as and perhaps more than the decision in Swain, Batson brings to the surface and appears to ratify crude and unbecoming ways of classifying human beings.

Were a court to demand a good (rather than merely a racially neutral) reason for the exclusion of a prospective juror (that is, if only challenges for cause were allowed), none of the troublesome propositions suggested above would infect the American law of jury selection. Courts would hear the reasons for a prospective juror's exclusion before deciding whether to exclude him or her; they would not await the exclusion of this juror (and others) before conducting a hearing on whether to conduct a hearing on whether the reasons for the juror's exclusion were racially neutral (albeit repugnant). Only the Supreme Court's desire to preserve the "wonderful power" of the peremptory challenge ${ }^{177}$ has led it to disapprove some invidious discrimination while apparently validating much more, and only this desire has led the Court to create cumbersome procedures for determining which peremptory strikes are not simply awful but awful and forbidden. ${ }^{178}$

Dissenting in Batson, Chief Justice Burger objected to the majority's limitation of the peremptory challenge and expressed more forcefully than the majority a desire to shield this challenge from change. Chief Justice Burger first argued that, because the peremptory challenge could not survive the application of basic equal protection standards, it should be exempted from conventional equal protection analysis:

[T] he Court also invokes general equal protection principles in support of its holding. But peremptory challenges are often lodged, of necessity, for reasons "normally thought irrelevant to legal proceedings or official action, namely, the race, reli-

${ }^{177}$ See Barbara A. Babcock, Voir Dire: Preserving "Its Wonderful Power", 27 Stan L Rev 545 (1975).

${ }^{278}$ See Chisolm v State, 529 S2d 635, 639 (Miss 1988) ("[T]he challenge cannot be exercised for a racially discriminatory reason. But this in no way precludes exercise of a peremptory challenge for a non-race based reason that objective and fair-minded persons might regard as absurd."). 
gion, nationality, occupation or affliations of people summoned for jury duty." . . . Moreover, in making peremptory challenges, both the prosecutor and defense attorney necessarily act on only limited information or hunch. The process can not be indicted on the sole basis that such decisions are made on the basis of "assumption" or "intuitive judgment." . . . As a result, unadulterated equal protection analysis is simply inapplicable to peremptory challenges exercised in any particular case. A clause that requires a minimum "rationality" in government actions has no application to " an arbitrary and capricious right" ". . . ; a constitutional principle that may invalidate state action on the basis of "stereotypic notions" ... does not explain the breadth of a procedure exercised on the "sudden impressions and unaccountable prejudices we are apt to conceive upon the bare looks and gestures of another." "179

Within a few pages, however, the Chief Justice abandoned his assertion of the primacy of practice over constitutional principle. After maintaining that equal protection standards and the peremptory challenge are hopelessly incompatible, he argued that the peremptory challenge can pass constitutional muster after all:

The Court never applies th[e] conventional equal protection framework to the claims at hand, perhaps to avoid acknowledging that the state interest involved here has historically been regarded by this Court as substantial, if not compelling. Peremptory challenges have long been viewed as a means to achieve an impartial jury .... Under conventional equal protection principles, a state interest of this magnitude and ancient lineage might well overcome an equal protection objection .... ${ }^{180}$

Chief Justice Burger was correct the first time. A compelling reason for acting on the basis of a whim, hunch or "unaccountable prejudice" is difficult to conceive. A prospective juror is subject to a challenge for cause whenever there is sound reason to consider him or her biased. It is only when prosecutors lack this "rational

179476 US at 123 (Burger dissenting) (citations omitted and emphasis supplied).

180 Id at 125. Although Chief Justice Burger emphasized the historic pedigree of peremptory challenges, in Blackstone's time peremptory challenges merely determined which male property owners served on juries. Because official discrimination had come earlier, these peremptory challenges were less likely than today's challenges to be exercised on invidious bases. Indeed, peremptory challenges do not seem to have been exercised very much at all. See text at notes 51-52. 
basis" for exclusion that they challenge jurors peremptorily. As the Chief Justice initially seemed to recognize, the tension between the Equal Protection Clause and the peremptory challenge is inescapable. The Equal Protection Clause says in essence, "When the government treats people differently, it has to have a reason." The peremptory challenge says in essence, "No, it doesn't."

Trial lawyers frequently observe that they use their peremptory challenges, not to secure impartial juries, but to secure juries likely to favor their positions. Nevertheless, the available evidence suggests that they often fall short of their partisan goals. Their folk wisdom, trial experiences, mystic intuitions, and crude group stereotypes do not in fact enable them to predict which jurors will favor their positions.

In an experiment conducted by Hans Zeisel and Shari Seidman Diamond, prospective jurors who had been struck by prosecutors and defense attorneys in twelve federal cases sat as "shadow juries" in these cases. In each case, the people who had been excluded by the lawyers observed the trial and were treated as much like the trial jurors as possible (seeing the same exhibits, leaving the courtroom when the jury was excluded, and the like). In a departure from ordinary practice, the excluded jurors were kept from knowing who had excluded them. Nevertheless, Zeisel and Diamond knew. They also knew the initial votes as well as the final verdicts of the trial juries. By comparing the votes of the trial jurors with those of the prospective jurors whom a lawyer had excluded, the researchers determined whether this lawyer had improved his or her position through the use of peremptory strikes.

They found that prosecutors had not. The prospective jurors whom government lawyers excluded were as likely to favor conviction as the jurors actually seated. Defense attorneys were somewhat more effective, but even their challenges were only marginally better than random guesses. ${ }^{181}$ Peremptory challenges provide opportunities for game playing and the exercise of pseudo-expertise by trial lawyers, but it seems doubtful that they accomplish much more. When lawyers cannot evaluate prospective jurors well enough to advance even their own tactical goals, the claim that their exclusions further broader public purposes seems strained. ${ }^{182}$

181 Hans Zeisel and Shari Seidman Diamond, The Effect of Peremptory Challenges on Jury and Verdict: An Experiment in Federal District Court, 30 Stan L Rev 491, 513-18 (1978).

182 Defenders of the peremptory challenge could fairly note that the lawyers studied by Zeisel and Diamond might have been more successful if they had been afforded greater 
Despite the findings of Zeisel and Diamond, litigants may often have rational grounds for their use of peremptory challenges in terms of their own primary objective-winning. Under the Equal Protection Clause, however, the issue is whether their classifications rationally advance a public or governmental interest-that is, whether the parties' duel of peremptory challenges produces a more impartial jury. Even if one assumes that lawyers can identify the jurors most likely to favor their opponents, the lawyers' offsetting challenges seem unlikely to further any public goal.

Imagine a statute that generalized the principle underlying any specific use of a peremptory challenge to exclude a prospective juror who could not be disqualified for cause. This statute might disqualify from jury service both people who smile at defense attorneys and people who smile at prosecutors, or it might disqualify from a jury anyone with a child the same age as the defendant and anyone with a child the same age as the complaining witness. Although the line drawn by this statute might be less offensive than many of the lines that lawyers draw in exercising peremptory challenges, it probably could not survive constitutional scrutiny. This statute might narrow the range from which the jury could be drawn, but the resulting jury would not appear more "impartial" than one drawn from a broader range. A statute that disqualified a prospective juror for smiling at a lawyer or for having a child of a particular age would lack a rational basis. The peremptory challenge is no better and often may be worse.

In Brown $v$ Rice, ${ }^{183}$ a prosecutor used his peremptory challenges to remove from the jury in a capital case all prospective jurors who expressed even slight reservations about capital punishment. Under the Supreme Court's decision in Witherspoon $v$ Illinois ${ }^{184}$ the disqualification of these jurors for cause would have violated the defendant's Sixth Amendment right to an impartial jury at the sentencing phase of his trial, ${ }^{185}$ and the federal district

opportunities to question prospective jurors during the voir dire examination. Similarly, proponents of the death penalty sometimes argue that capital punishment might have a more demonstrable deterrent effect if it were applied more broadly and uniformly, and proponents of efforts to rehabilitate criminals sometimes dismiss negative empirical evaluations by pointing to the possibility of establishing more ambitious rehabilitative programs than any yet evaluated. It is always possible to do more; but when the costs of doing more appear unjustified, the failure of current practices suggests doing less.

183693 F Supp 381, 389-94 (W D NC 1988).

184391 US 510 (1968).

${ }^{185}$ In post-Witherspoon declarations, the Supreme Court has said that no exclusion from a jury can violate the Sixth Amendment so long as the people who remain on the jury 
court in Brown concluded, "The ultimate outcome of a jury organized to return a verdict of death is no less partial when achieved through peremptory challenges than when achieved through challenges for cause."186

In one respect, the peremptory challenges invalidated in Brown differed from the disqualification invalidated in Witherspoon. The defendant's attorney might have challenged unequivocal proponents of the death penalty while the prosecutor challenged people who voiced reservations about this penalty. The mutual power of these attorneys to whittle away at society was unlike a disqualification that favored one side. The Batson decision, however, rejected the proposition that two wrongs make a right. The ability of the defense attorney in Brown to exclude enthusiastic proponents of the death penalty no more justified the prosecutor's challenges than the ability of the defense attorney in Batson to challenge whites justified the prosecutor's elimination of blacks.

In addition, the distribution of groups targeted by prosecutors and defense attorneys is unlikely to be symmetrical. Ninety percent of a community may be German-American and ten percent black. Similarly, eighty percent may be enthusiastic proponents of capital punishment while twenty percent may have reservations about this penalty. In a particular community, the prosecutor may be able to eliminate all blacks from a jury or all jurors with reservations about the death penalty while the defense attorney may not be able to eliminate all German-Americans or all enthusiastic proponents of capital punishment. A jury reflecting the median of the community may be little different from a jury drawn from one of the poles. This jury, composed entirely of representatives of one distinctive group, may be far from a representative cross section of the community. Whatever the distribution of groups and attitudes in a community, things are unlikely to come out even. If the Supreme Court were to reject the position of the district court in Brown, its decision might do for the holding in Witherspoon what the Court's decision in Swain did in Talledega County for the

can judge the case fairly. In the "special context of capital sentencing," however, the Sixth Amendment continues to forbid "the effects of an 'imbalanced jury" and to require an examination of exclusions as well as inclusions. See Lockhart $v$ McCree, 476 US 162, 182-84 (1986). To the Supreme Court, the language of the Sixth Amendment carries a variety of meanings.

${ }^{186}$ Brown, 693 F Supp at 392. Four Supreme Court Justices have rejected the position of the District Court in Brown. See Gray v Mississippi, 107 S Ct 2045, 2062 (1987) (Scalia dissenting, joined by three other Justices), and so has the North Carolina Supreme Court. See also State v Fullwood, 373 SE2d 518 (NC 1988). 
holding in Strauder-reduce that earlier ruling to a symbol. ${ }^{187}$

From a prosecutor's perspective, however, it is difficult to imagine a more rational basis for the use of peremptory challenges than the one held unconstitutional in Brown. The court's decision reveals how little might be left of the peremptory challenge if it were subjected to ordinary constitutional restraints. When a prosecutor may not challenge prospective jurors in a capital case because these jurors have expressed reservations about the death penalty, one wonders what this prosecutor may do instead-challenge prospective jurors who are round-faced and jovial or who wear campaign buttons advocating "Cuomo for President in 1992?" If surrogates for the forbidden criterion are impermissible, what remains? The prosecutor in Brown presumably decided to ask for the death penalty because he believed that the defendant deserved it. If the case is retried, how close may the prosecutor come to obtaining the hanging jury that he seeks? Ordering the prosecutor to exercise his peremptory challenges but not to seek a jury stacked in favor of the death penalty commands the impossible; the peremptory challenge would be better abolished, at least in capital cases in which the Witherspoon standards apply.

Although peremptory challenges could rarely survive even minimal "rational basis" scrutiny under the Equal Protection Clause, the claim that these challenges serve useful purposes cannot entirely be dismissed. ${ }^{188}$ On occasion, unexplained challenges have provided a gentle way of excluding prospective jurors who probably should not have been permitted to serve. When a prospective juror has told the court that he or she can be impartial, rejecting this assurance and excluding the juror for cause is likely to seem insulting. In this situation, the peremptory challenge has permitted both judges and prospective jurors to save face. Judges have resolved their doubts against exclusion, relying on the peremptory challenge to correct their errors and to do so without explicitly rejecting the jurors' protestations of impartiality.

Practitioners report in fact that judges often ask questions designed to secure declarations of impartiality, then treat these declarations as conclusive. Practitioners also maintain that neither the prosecutor, defense attorney, nor judge may trust the fairness of a juror whose statements provide no basis for exclusion but whose manner seems erratic. They suggest that the peremptory challenge permits the removal of "three dollar bills" from the jury.

187 See text at notes $42-47$.

${ }^{188}$ See Babcock, 27 Stan L Rev 545 (cited in note 177). 
One may wonder whether the identification of people as "three dollar bills" is shaped by the lawyers' prejudices and to what extent intuitions not capable of verbalization should be credited. On the assumption that lawyers and judges can accurately identify "three dollar bill jurors," however, devices other than the peremptory challenge could keep these jurors' actions from infecting jury verdicts. For one thing, current standards for exclusion for cause might be altered. Without requiring a finding of partiality, these standards might permit the exclusion of any juror whose ability or fairness appeared open to doubt. In addition, the Supreme Court has upheld the constitutionality of nonunanimous jury verdicts in state criminal cases-a procedure that denies idiosyncratic jurors the ability to frustrate the judgments of others. ${ }^{189}$

Finally, following the voir dire examination of a somewhat larger number of prospective jurors than the number to be empaneled, a trial judge might be permitted to select on a discretionary basis those jurors who appeared best qualified to decide the case impartially. If the judge saw no reason to doubt any prospective juror's ability or fairness, the judge might use a random selection process instead, and someone not included on the jury might be left unaware whether chance or judgment had led to his or her exclusion. ${ }^{190}$

This procedure might be characterized as affording peremptory challenges to the judge rather than to counsel, but the characterization would not be entirely accurate. A judge would not be empowered to dismiss a juror for any reason that struck his or her fancy (for example, disapproval of the juror's necktie or gender), but only to make comparative evaluations of the ability and fairness of prospective jurors. The judge's responsibility would not differ from that of any other official authorized to make hiring decisions on a discretionary basis; and although a partisan or biased judge could abuse his or her power, discretionary hiring does not

189 See Apodaca v Oregon, 406 US 404 (1972). Were the abolition of peremptory challenges to lead to an increased use of nonunanimous jury verdicts, I confess that I would not regard the change as progress. Jury unanimity reinforces the sense that criminal convictions manifest a high degree of certainty of guilt, a sense that furthers the criminal law's ability to fulfill its distinctive mission. See Henry M. Hart, Jr., The Aims of the Criminal Law, $23 \mathrm{~L}$ \& Contemp Probs 401, 402-06 (1958).

190 This "masking" procedure might not always be necessary, however. A judge often could voice the reason for his or her exclusion without insulting the excluded juror: "Mr. Smith, I have no doubt that you could judge this case fairly; but because you were the victim of a serious crime ten years ago and because I cannot be sure that the trial won't resurrect some difficult memories for you, I've decided that it would be better to let other jurors hear this case." 
violate the Constitution. The discretion of a judge to select capable and impartial jurors would be likely to advance the public's interest in securing a capable and impartial jury; the exercise of peremptory challenges by advocates who seek favorable rather than impartial jurors cannot be expected to further this goal. Affording judges a greater discretion in the selection of jurors than they now possess would have a rational basis that current procedures lack. If "three dollar bill jurors" can be identified and should in fact be excluded, the Constitution permits an impartial judicial officer to exclude them.

Abolishing the peremptory challenge might require courts to consider challenges for cause more carefully and to uphold them more frequently, and the line-drawing process could become more difficult than ruling on challenges for cause is today. Were a court to reject a Klansman's claim that he could fairly judge the case of a black defendant, the court might confront a similar challenge to the impartiality of a member of a social organization (perhaps the Elks Club) that excludes blacks from membership. A court also might confront claims that a member of the National Organization for Marihuana Legalization could not fairly try a drug-possession case, that a person wearing a button or a jacket with a peace symbol could not fairly try a draft-evasion case, and that a reputed member of a street gang could not fairly serve in any case. Submerging some issues in the ambiguity of the peremptory challenge could be useful. ${ }^{191}$

In an adversary system, however, peremptory challenges cannot be confined to cases in which they permit judges to avoid difficult issues and in which they permit appropriately excluded jurors to save face. Preserving the peremptory challenge as a face-saving device in cases close to the line of appropriate exclusion for cause guarantees irrational and invidious discrimination in countless cases far from the line.

When discretion is likely to be abused, the Supreme Court sometimes has interpreted the Constitution to forbid the exercise of discretion. The Court held in Delaware $v$ Prouse ${ }^{192}$ for example, that random stops of motorists to check drivers' licenses are unconstitutional. It noted at the same time that stopping all motorists at roadblocks would "not involve the unconstrained exercise of discretion" and therefore might not violate the Fourth Amend-

191 See Babcock, 27 Stan L Rev at 553-54 (cited in note 177).

182440 US 648 (1979). 
ment. ${ }^{193}$ With some exceptions, the Court has treated nondiscretionary administrative standards as indispensable to the constitutionality of administrative searches. ${ }^{194}$ Similarly, the Court has held that ordinances requiring permits for parades, for the distribution of literature, or for other forms of speech are unconstitutional unless they supply standards to guard against the denial of permits for impermissible reasons. Although no licensing official might have abused his or her discretion, the Court has concluded that the danger posed by standardless ordinances is too great. ${ }^{195}$

The danger of unconstitutional abuse posed by the exercise of peremptory challenges by partisan advocates is probably greater than that posed by the discretion of officials to make random license checks or to grant parade permits without standards. Even racial discrimination is unlikely to yield to the cumbersome, costly, and easily evaded controls created by the Batson decision, and efforts to restrict countless other forms of discrimination through Batson-like procedures would be hopeless. In addressing discrimination against women, the handicapped, and other groups (including, perhaps, jurors with thin lips who rarely smile), courts might consider the adequacy of prima facie showings, assess the adequacy of proffered explanations, and order expensive but largely ineffective remedies on a case-by-case basis. Were courts to undertake this task, however, they might be too busy to undertake many others.

Few peremptory challenges could survive even rational basis scrutiny under the Equal Protection Clause. These challenges are not worth saving. The amount of protective buffering in a prophylactic rule prohibiting the peremptory challenge altogether would be small and the costs of this rule minimal. ${ }^{196}$ The gains would include substantial economic savings, the effective control of racial and other widely condemned forms of group discrimination, and the control of countless other, less frequently employed, less generalized classifications that insult and diminish human beings.

193 Id at 663.

${ }^{204}$ See, for example, Camara v Municipal Court, 387 US 523, 538 (1967) (requiring "reasonable legislative or administrative standards for conducting an area inspection" to search for building code violations).

${ }^{195}$ See, for example, Lovell v Griffin, 303 US 444 (1938); Shuttlesworth v Birmingham, 394 US 147, 150-51 (1969). See generally David A. Strauss, The Ubiquity of Prophylactic Rules, 55 U Chi L Rev 190 (1988).

${ }^{196}$ See Rakas v Illinois, 439 US 128, 147 (1978) ("Where the factual premises for a rule are so generally prevalent that little would be lost and much would be gained by abandoning case-by-case analysis, we have not hesitated to do so."). 
In his concurring opinion in Batson, Justice Marshall quoted a manual formerly used to instruct Dallas, Texas, prosecutors in the art of jury selection. ${ }^{197}$ The person who leaked a copy of this confidential manual to the source cited by Justice Marshall ${ }^{198}$ also leaked a copy to me. Some excerpts may help to place the constitutional issue in context:

You are not looking for a fair juror, but rather a strong, biased and sometimes hypocritical individual who believes that Defendants are different from them in kind, rather than degree. You are not looking for any member of a minority group which may subject him to oppression-they almost always empathize with the accused. You are not looking for the free thinkers and flower children.

Observation is worthwhile. Look at the panel out in the hall before they are seated. You can often spot the showoffs and the liberals by how and to whom they are talking. Observe the veniremen as they walk into the courtroom. You can tell almost as much about a man by how he walks, as how he talks. Look for physical afflictions. These people usually sympathize with the accused.

I don't like women jurors because I can't trust them. They do, however, make the best jurors in cases involving crimes against children. It is possible that their "women's intuition" can help you if you can't win your case with the facts. . . .

Extremely overweight people, especially women and young men, indicates a lack of self-discipline and often times instability. I like the lean and hungry look. ....

If the veniremen have not lived in the county long, ask where they were born and reared. People from small towns and rural areas generally make good State's jurors. People from the east or west coasts often make bad jurors. ....

Intellectuals such as teachers, etc. generally are too liberal and contemplative to make good State's jurors. ... 
Ask if the venireman has any hobbies or interests that occupy their spare time. Active, outdoors type hobbies indicate the best State's jurors. Hunters always make good State's jurors.

Ask men if they have ever served in the military; if so, when, what branch of the service, their rank upon discharge and if they saw combat. Marines, master sargeants and those that have seen combat generally make good State's jurors.

Ask veniremen their religious preference. Jewish veniremen generally make poor State's jurors. Jews have a history of oppression and generally empathize with the accused. Lutherans and Church of Christ veniremen usually make good State's jurors. ${ }^{189}$

This training manual probably did not capture the practices of most prosecutors when it was written fifteen years ago, and one hopes that times have changed. Although much of the manual seems ridiculous, the ridicule should not be directed primarily to prosecutors, the Dallas District Attorney's Office, or even the manual's author. A more appropriate object of this ridicule is the peremptory challenge itself. In selecting juries, defense attorneys behave like prosecutors in reverse; and when a trial lawyer must exercise peremptory challenges on the basis of limited information, crude, insulting stereotypes may provide as plausible a basis for action as any that he or she has.

Within broad limits, setting aside only the manual's most outrageous propositions, a prosecutor who follows its suggestions does what the regime of peremptory challenges invites and encourages him or her to do and indeed all but ensures that he or she will do. In the United States, a legal institution that leads people to view other people in the terms revealed by this manual and to make governmental decisions on the bases it suggests cannot be constitutional.

\section{The Review of JuRy Verdicts}

A. The Judicial Acceptance of Inconsistent Verdicts

Just as our courtroom procedures often treat jurors as children, our rules concerning the review of jury verdicts suggest that

199 Jon Sparling, Jury Selection in a Criminal Case (unpublished, undated) (lettering and headings omitted) (on file, University of Chicago Law Review office). 
jurors cannot be held to adult standards of responsibility. The practice of accepting inconsistent jury verdicts illustrates our exemption of jurors from the review customarily afforded other governmental officials. A court may instruct a jury, for example, not to convict a defendant of conspiracy unless the Government proves that the defendant not only agreed to commit a crime but actually committed it; the substantive offense may be the only overt act in furtherance of the conspiracy that the Government has alleged. If the jury convicts the defendant of conspiracy but at the same time acquits him or her of the substantive offense, its inconsistent verdicts reveal either a misunderstanding or a violation of the court's instructions. Nevertheless, the federal courts and most state courts simply enter judgment on the verdicts. ${ }^{200}$

Courts justify their toleration of jury inconsistency by presuming that the jurors disregarded their oaths and chose to be merciful rather than just. The jurors presumably recognized the defendant's guilt of the crime of which they acquitted but concluded that a single conviction was enough. Frequently, however, a hypothesis less flattering to the jurors' intelligence would be as plausible: The jurors misunderstood rather than defied the court's instructions. The jurors might have thought, for example, that a defendant could appropriately be convicted of conspiracy upon proof of agreement without proof of any overt act. On the jury's view of the facts, the defendant might not have been guilty of any crime.

Rejecting substantial authority to the contrary, ${ }^{201}$ the Supreme Court adopted the rule upholding inconsistent jury verdicts in 1932 in Dunn v United States. ${ }^{202}$ Offering the standard rationale for the rule, Justice Holmes quoted the language of a lower court:

"The most that can be said in such cases is that the verdict shows that either in the acquittal or the conviction the jury did not speak their real conclusions, but that does not show that they were not convinced of the defendant's guilt. We interpret the acquittal as no more than their assumption of a power which they had no right to exercise, but to which they were disposed through lenity."203

${ }^{200}$ See LaFave and Israel, Criminal Procedure $\$ 23.7(\mathrm{e})$ at $48-49$ (cited in note 121); United States v Powell, 469 US 57 (1984).

${ }^{201}$ See Dunn $v$ United States, 284 US 390, 400-07 (1932) (Butler dissenting) (citing and describing cases).

${ }^{202}$ Id.

${ }^{203}$ Id at 393 (quoting Steckler v United States, 7 F2d 59, 60 (2d Cir 1925)). 
In other words, rather than guard against unlawful conviction, courts will presume unlawful acquittal. If either a conviction or an acquittal must be erroneous, courts will assume that the error lies in the acquittal alone. The message of Dunn seems to be: Better that ten innocent defendants be convicted than that ten guilty defendants be denied the boon of unlawful jury nullification on some counts of their multiple count indictments.

By 1984, lower federal courts had created several exceptions to the Dunn rule. The Supreme Court therefore reexamined this rule in United States $v$ Powell. ${ }^{204}$ In his opinion for the Court, Justice Rehnquist rejected the lower courts' exceptions, reiterated Justice Holmes' argument for the rule, and added a rationale of his own. "Inconsistent verdicts," he wrote, "present a situation where "error,' in the sense that the jury has not followed the court's instructions, most certainly has occurred, but it is unclear whose ox has been gored."20s If a defendant's acquittal of one crime rather than his or her conviction of another was erroneous,

the Government has no recourse if it wishes to correct the jury's error; the Government is precluded from appealing or otherwise upsetting such an acquittal by the Constitution's Double Jeopardy Clause. . . . . Given th[e] uncertainty [of whether the defendant or the government has profited from the error] and the fact that the Government is precluded from challenging the acquittal, it is hardly satisfactory to allow the defendant to receive a new trial on the conviction as a matter of course. ${ }^{208}$

In other words, although a defendant's conviction might be erroneous, he or she may not challenge it because the framers of the Constitution afforded him or her the protection of the Double Jeopardy Clause (thereby precluding the Government from challenging the defendant's possibly erroneous acquittal). Seeking a symmetry that the framers of the Double Jeopardy Clause failed to provide, the Supreme Court hammered the defendant's shield into the prosecutor's sword. Partly because of her constitutional privilege, the defendant in Powell went to prison; without it, she might have been free.

Inconsistency in a jury's verdicts is usually apparent before a court accepts these verdicts, and correction of the jury's error

204469 US 57 (1984).

205 Id at 65.

200 Id. 
could come at little cost. For many courts, however, correcting the errors of juries is less important than indulging jury "vagaries." These courts recognize that their romanticized view of jury verdicts may not be accurate; but disregarding the possibility of factual mistake and the risk of unfair conviction, they treat the inconsistencies of juries as folk justice rather than as error. ${ }^{208}$

\section{B. Judicial Review of the Sufficiency of the Evidence}

Courts also defer to irrational jury determinations of fact. In assessing the sufficiency of the evidence to support a conviction, they employ a standard that, if they meant it, would amply guard against unjust conviction. A conviction may not stand when "a reasonably minded jury must necessarily have entertained a reasonable doubt as to defendant's guilt."200 This rule, however, is hedged with subordinate rules that sharply limit the power of judges:

All reasonable inferences which tend to support the Government's case must be accepted. Any conflicts in the evidence must be resolved in the Government's favor. . . . "It is not properly the function of the court ... to assess the credibility of witnesses, weigh the evidence, or substitute its own judgment as to the guilt or innocence for that of the jury."210

On this view, courts look exclusively to the government's side of the case and ask whether the prosecutor presented some evidence of every element necessary to establish the offense charged.211 They disregard evidence presented by the defendant unless it fills gaps left by the prosecutor.

For example, in a case in which a defendant has been found in possession of a stolen automobile and charged with knowingly receiving stolen property, the state's case may depend entirely on the testimony of an admitted car thief who claims to have lent the automobile to the defendant, informing him of its stolen character.

${ }^{207}$ See United States $v$ Dotterweich, 320 US 277, 279 (1943).

${ }^{208}$ Appellate courts ordinarily do not permit trial judges to render inconsistent judgments in cases tried without juries. See United States v Maybury, 274 F2d 899, 902-903 (2d Cir 1960); Lafave and Israel, Criminal Procedure \$23.7(e) 48-49 (cited in note 121). Nevertheless, at least in some circumstances, a state may allow trial judges to render inconsistent judgments without violating the Constitution. See Harris v Rivera, 454 US 339, 346-47 (1981).

${ }^{209}$ See, for example, United States v Palmere, 578 F2d 105, 106 (5th Cir 1978).

210 United States v Burns, 597 F2d 939, 941 (5th Cir 1979) (quoting United States $v$ Brown, 587 F2d 187, 190-91 (5th Cir 1979)).

${ }^{211}$ See, for example, United States v Beck, 615 F2d 441, 448 (7th Cir 1980). 
This witness may have changed his story frequently; he may have exculpated the defendant on several prior occasions; he may have a long history of crimes of dishonesty; the government may have offered him leniency in exchange for his testimony; and his testimony may be uncorroborated by other circumstances. Nevertheless, because the assessment of credibility is for the jury, his evidence is legally sufficient to support the defendant's conviction.

Similarly, a victim's initial identification of a defendant may have been obtained under suggestive circumstances; the defendant may not have matched the physical description that the victim gave the police following the crime; the defendant may have offered an alibi and supported it with the testimony of an apparently disinterested witness; and he also may have presented strong physical evidence corroborating his alibi. If, however, the victim has positively identified the defendant, the evidence is sufficient to support his conviction under customary standards. ${ }^{212}$

To be sure, courts sometimes bend their stated standards in extreme cases. Moreover, although courts may not assess the credibility of witnesses in judging the sufficiency of the evidence, they may assess credibility in deciding whether to order new trials. Their discretion to order new trials is to be exercised "sparingly"213 and only in "exceptional cases in which the evidence preponderates heavily against the verdict." 14 Nevertheless, a second jury may return the same verdict as the first; and in this situation, a judge is likely to disregard the fact that the evidence still "preponderates against the verdict" and send to prison a defendant whom the judge believes to be innocent. ${ }^{215}$

During most of the history of the common law, the power of

212 For a detailed description of a case like this one-a case in which a jury convicted, in which the conviction was affirmed by an intermediate state appellate court, but in which the state supreme court did not defer to the jury's determination of credibility-see my paper, Walter V. Schaefer: An Appreciation, 32 U Chi L Sch Rec 62, 63-64 (1986).

${ }_{213}$ United States v Mancini, 396 F Supp 75, 78 (E D Pa 1975).

214 United States $v$ Wilson, 178 F Supp 881, 884 (D DC 1959)(citation omitted.)

215 Id. A judge need not acquiesce in the verdict of a second jury, however. So long as the evidence "preponderates heavily against the verdict," the judge may order a third trial, a fourth, or a fifth. If a judge is willing to uphold only a verdict of acquittal, one wonders why the judge may not order an acquittal directly. This question occurred to Judge Jack B. Weinstein, who used a complex procedure to raise the issue in a form that enabled the Second Circuit to resolve it. In an opinion by Judge Henry Friendly, the court ruled that Judge Weinstein had no authority to order an acquittal or dismissal in a case in which the principal government witness was unbelievable and there was no prospect that the government could present additional evidence at a second trial. Judge Weinstein apparently could, however, grant new trials ad infinitum. United States $v$ Weinstein, 452 F2d 704, 716 (2d Cir 1971). 
judges to guard against conviction of the innocent was substantially broader. Although common law judges could not formally direct verdicts of acquittal, they gave jurors their views of the facts as well as the law, and their recommendations in favor of acquittal were very likely to be followed. If, in a rare case, a jury disregarded the judge's opinion, the judge could recommend a pardon with full assurance that the Crown would grant it as a matter of course. ${ }^{216}$ The historic struggle for jury independence in England focused on the efforts of judges to force conviction and to punish jurors who acquitted for rendering verdicts contrary to the evidence. The judges' practical power to free defendants whose guilt they doubted was not a source of controversy. ${ }^{217}$

In the early part of the twentieth century, courts sometimes manifested a stronger sense of their responsibility to ensure the guilt of the people whom they punished than judges do today:

[It is] the duty of the trial court to carefully weigh and consider all the evidence and the facts and circumstances in the case, and unless satisfied with the verdict to such an extent that its reason and judgment approve it, a new trial should be granted. And "the approval of a verdict does not mean ... formal approval ... but ... the assent and approval of the mind after due consideration; and when the mind of the court refuses to concur in the correctness of a verdict, and its honest convictions lead it to believe that it ought to have been for the other party, then the verdict is not supported by the evidence so as to merit its approval. . . . It cannot be said that a court approves a verdict when its reason and judgment rebel against the conclusion it expresses. ..." "[I]t is the imperative, abiding duty of the court ... to carefully weigh the entire matter, and, unless it is satisfied that the verdict is responsive to the demands of justice, to set the verdict aside and grant a new trial. . .." [T] the trial court should . . . entertain a firm belief in the justness of the verdict before pronouncing judgment. ${ }^{218}$

${ }^{218}$ See John H. Langbein, The Criminal Trial Before the Lawyers, 45 U Chi L Rev 263, 296 (1978); Green, Verdict According to Conscience at 139-40 (cited in note 52); Weinstein, 452 F2d at 715 (collecting sources).

${ }^{217}$ See generally Green, Verdict According to Conscience at 150-152 (cited in note 52).

${ }^{213}$ Piel v People, 52 Colo 1, 7-10, 119 P 687, 689-90 (1911) (quoting Yarnell v Kilgore, 15 Okl 591, 593, 82 P 990 (1905) and Hogan v Bailey, 27 Okla 15, 110 P 890, 892 (1910)). But see St. Louis v People, 120 Colo 345, 353, 209 P2d 538, 541 (1949) ("In the opinion in the Piel case there is language which might justify one in assuming that we held that the trial judge is a super thirteenth juror vested with the power and authority of determining whether the jury has reached a proper verdict upon conflicting evidence ..., but we do not 
Although the standard of review suggested by this language may be too stringent, today's broad deference to jury determinations of credibility is also unwarranted. The appropriate standard is the one generally accepted - whether a reasonable jury could have found guilt beyond a reasonable doubt. Nevertheless, courts should apply this standard after reviewing all the evidence in a case, including that presented by the defendant. To the extent that determinations of credibility appropriately rest on the demeanor of witnesses, judges should defer to jury determinations of credibility; but to the extent that fair determinations of credibility rest on more objective circumstances, courts need not exempt the assessment of credibility from review. ${ }^{219}$

Appellate judges frequently note the dangers of basing their review on a "cold" record, suggesting that "even the best and most accurate record of oral testimony is like 'a dehydrated peach; it has neither the substance nor the flavor of the peach before it was dried." "220 The importance of demeanor evidence is often overstated, however, and few appellate judges have proposed the use of videotape technology to enable them to review witness testimony in color.

The assessment of credibility is not a mystical process that must be left to the intuitions of unreviewed, hopefully clairvoyant jurors. The task depends less on the ability of jurors to stare deeply into a witness's eyes than it does on the jurors' ability to judge the internal coherency of the witness's story, its consistency with known external circumstances, and the witness's past conduct, statements and character. Judicial review on the basis of a "cold" record has its virtues and can safeguard at least part of this process. The opportunity to leave the emotions of the closing argu-

so construe it."); People v Emeson, 179 Colo 308, 312, 500 P2d 368, 369-71 (1972) ("It is elemental that a trial judge may never upset a guilty verdict for the sole reason that if he were the finder of fact, he would have ruled differently. If the evidence, although conflicting, supports the jury's verdict of guilty, the verdict must be upheld.").

The language quoted in text did not reflect the dominant view of early twentieth century courts. As recently as 1957 , however, one commentator noted that "a small and waning number of courts have suggested that submission of a case to the jury is improper unless the only conclusion which the evidence permits is that of guilt beyond a reasonable doubt." Comment, Judgments of Acquittal: The Right to a Non-Jury Trial, 24 U Chi L Rev 561, 564 (1957).

210 A court might assume that all prosecution witnesses spoke with poise and self-assurance while all defense witnesses had sweaty palms, quavering voices, and shifty eyes. If a reasonable jury would nevertheless have had a reasonable doubt of the defendant's guilt, the court should not permit a verdict of guilty to stand.

220 State v Gilmore, 103 NJ 508, 511 A2d 1150, 1170-71 (1986) (Clifford dissenting) (quoting Trusky v Ford Motor Co, 19 NJ Super 100, 104, 88 A2d 235 (1952)). 
ments behind, to escape the interplay of courtroom personalities, and to sort out times, places, and contradictions in a relatively leisurely fashion can yield important insights. Judges have no higher responsibility than ensuring that the innocent are not punished for crime; and the careful judicial review of jury findings, including those turning on jury assessments of credibility, can contribute to this goal.

C. The Courts' Refusal to Permit the Impeachment of Jury Verdicts by Jurors

The refusal of courts to allow jurors to "impeach" their verdicts by confessing misconduct illustrates once more our failure to hold jurors to ordinary standards of responsibility. In Tanner $v$ United States, ${ }^{221}$ the Supreme Court excluded a voluntary confession of serious misconduct and revealed its sympathy for the view that adolescents will be adolescents and so will jurors.

On their own initiative, two of the jurors in Tanner approached the defense attorney shortly after the jury had convicted two federal co-defendants of conspiracy and mail fraud. The jurors' statements, taken together, ${ }^{222}$ suggested that the foreperson of the jury was an alcoholic who regularly drank a liter of wine during the court's noon recess. Two other jurors consumed mixed drinks. Four preferred beer, drinking one to three pitchers together during midday breaks. In a sworn statement, one member of this group reported that, although their drinking did not make the jurors "drunk," some were "falling asleep all the time during the trial." 223 This juror confessed that his own reasoning ability was affected on one day of the trial.

In addition, the juror reported that he and three others had smoked marihuana on "just about every day" of the trial. $\mathrm{He}$ added that a juror had sold a quarter pound of marihuana to another during the trial; that two had snorted "a couple lines" of cocaine on several occasions; that these same jurors sometimes had

221107 S Ct 2739 (1987).

${ }^{222}$ The juror who first approached the defense attorney apparently had not participated in the misconduct that she described. Although her statement was consistent with that of a second juror who confessed his own misconduct, the second juror's statement was more dramatic and complete. Most of the allegations described in text proceeded from the second juror. Id at 2744-45.

${ }^{223}$ Id at 2750. The other juror-informant also reported that several of the drinking jurors had slept through the afternoons of the trial. During the trial, the defense attorney had called the judge's attention to the fact that "a couple of jurors in particular have been taking long naps." Id at 2744 . The judge himself, however, did not see any juror asleep. 
used alcohol, cocaine, and marihuana together; and that one juror had "talked about how he was flying"-a statement indicating to the informant that the juror was "messed up." This informant characterized the trial as "one big party."224

The issue in Tanner was not whether these allegations should have led to a new trial but only whether the trial court should have conducted a hearing at which other jurors could be heard. ${ }^{225}$ To this question, the Supreme Court just said no.

\section{Rule. \\ 1. The Court's Interpretation of the Governing Federal}

The Supreme Court relied on Federal Rule of Evidence 606(b), which it described as "grounded in the common-law rule against admission of jury testimony to impeach a verdict . . . ."226 The Federal Rule, however, does not prohibit jurors from impeaching their verdicts. As the Advisory Committee Note on the Rule explains, "The familiar rubric that a juror may not impeach his own verdict ... is a gross oversimplification. ... [S]imply putting verdicts beyond effective reach can only promote irregularity and injustice."227 Moreover, as the four dissenting Justices in Tanner observed, the terms of the Rule do not apply to allegations of objective misconduct occurring prior to a jury's deliberations. ${ }^{228}$

Rule 606(b) contains two prohibitions. Subject to some exceptions, it first prohibits a juror from testifying "to any matter or statement occurring during the course of the jury's deliberations." This language plainly does not restrict testimony concerning drug

224 Id at 2745.

${ }^{223}$ One of the juror-informants had named another juror who, she said, would confirm her allegations of misconduct; but the trial judge had denied the defense counsel permission to interview this juror or any of the others. The Supreme Court complained that defense counsel had "clearly violat[ed]" the court's order by taking a formal statement from a juror shortly after this juror had contacted the attorney on the juror's own initiative. Id at 2750. It said that "on this basis alone" the trial judge could have disregarded the juror's statement. The Court thereby took a more favorable view of the exclusion of probative but improperly obtained evidence than it has taken in other contexts. See, for example, United States $v$ Leon, 468 US 897, 916-919 (1984) (in the absence of misconduct by police officers, the Fourth Amendment exclusionary rule does not reach the products of even deliberate constitutional violations by magistrates and judges). One wonders whether the defense attorney in Tanner acted in "objectively reasonable good faith" in concluding that the court's order did not preclude taking an affidavit from a juror who had come forward without prompting.

$228107 \mathrm{~S} \mathrm{Ct}$ at 2748.

${ }^{227}$ Advisory Committee's Note, FRE 606(b) (in Jack B. Weinstein, et al, eds, Evidence: Rules and Statute Supplement 58 (Foundation, 1984)).

228 Id at 2757. 
or alcohol abuse that has occurred prior to a jury's deliberations. Second, the Rule forbids a juror's testimony concerning "the affect of anything upon his or any other juror's mind or emotions as influencing him to assent or to dissent from the verdict or indictment or concerning his mental processes in connection therewith." Subject to the Rule's exceptions, this language probably prohibits a juror's testimony concerning the effect of alcohol or drug abuse on the juror's attentiveness or on his or her other mental processes, but it does not restrict testimony concerning the alcohol and drug abuse itself. In this respect, the Rule embodies a distinction that has found frequent expression in American cases. For example, an opinion by Justice Brennan during his service on the New Jersey Supreme Court declared that the testimony of jurors should be received when it "goes, not to the motives or methods or processes by which they reached the verdict, but merely to . . . the occurrence of events bearing on the verdict."229

The Supreme Court did not explain how the language of the Federal Rule could be construed to reach testimony concerning alcohol and drug abuse that had occurred prior to a jury's deliberations. ${ }^{230}$ Instead the Court focused on an exception to the Rule's prohibitions: "[A] juror may testify on the question . . . whether any outside influence was improperly brought to bear upon any juror." ${ }^{\text {"31 }}$ The Court ruled that alcohol, marihuana and cocaine were

228 The opinion added:

Evidence of the actual effect of the extraneous matter upon jurors' minds can and should be excluded, as such evidence implicates their mental processes, but receiving their evidence as to ... the happening of the event ... supplies evidence which can be put to the test of other testimony ... and ... can serve to avert ... a grave miscarriage of justice, which it is certainly the first duty of a court of conscience to prevent if at all possible.

State v Kociolek, 20 NJ 92, 100, 118 A2d 812, 816 (1955). For a court to permit testimony concerning an event whose relevance depends on its tendency to prejudice jurors while forbidding any testimony concerning whether the prejudicial effect materialized seems odd. The position articulated by Justice Brennan reflected the dubious application of a generally plausible doctrine-one forbidding juror testimony about subjective error or misconduct unconfirmed by objective circumstances (testimony, for example, concerning a juror's subjective misunderstanding of appropriate jury instructions). Although the view articulated by Justice Brennan and later adopted by the Federal Rule was a minority position, it had been accepted in some jurisdictions since the mid-nineteenth century. See, for example, Wright $v$ Illinois \& Miss. Tel. Co., 20 Iowa 195, 210-12 (1866); Perry v Bailey, 12 Kan 539, 544-45 (1874) (jurors may testify concerning "those things which are matters of sight and hearing" but not concerning their subjective mental processes-this rule permits a juror's testimony concerning another juror's intoxication).

${ }^{230}$ The Court did indicate that counsel had not raised this issue. $107 \mathrm{~S} \mathrm{Ct}$ at 2748.

${ }^{231}$ FRE 606(b). 
not "outside influences." 232

\section{The Incongruity and Unfairness of the Rule Forbidding} the Impeachment of Jury Verdicts.

The common law rule to which the Supreme Court referred in Tanner was not the rule during most of the history of the common law. ${ }^{233}$ This rule originated in a decision by Lord Mansfield shortly before the framing of the American Constitution. In Vaise $v$ Delaval, ${ }^{234}$ Mansfield rejected the affidavits of two members of a jury that the jury had reached its verdict by lottery. Mansfield nevertheless observed hypothetically that the testimony of a person who had "seen the transaction through a window" could be received.

As Dean Wigmore observed, Vaise v Delaval apparently rested on a civil law maxim of which Mansfield was especially fond: "A witness shall not be heard to allege his own turpitude." ${ }^{235}$ Following Mansfield's service on the Court of King's Bench, courts quickly repudiated this maxim in most areas of law. ${ }^{238}$ The princi-

$232107 \mathrm{~S} \mathrm{Ct}$ at 2750 . At the time of the Tanner decision, two leading commentaries on the Federal Rules of Evidence had concluded that the exception to Rule 606(b) would permit jurors to testify to intoxication even within the jury room. See David Louisell and Christopher Mueller, 3 Federal Evidence $\S 289$ at 143-144 (Law Co-op, 1979) ("[T]he present exception paves the way for proof by the affidavit or testimony of a juror that one or more jurors became intoxicated during deliberations."); Jack B. Weinstein and Margaret A. Berger, 3 Weinstein's Evidence \$606[04] (Foundation, 1985) ("Rule 606(b) would not render a witness incompetent to testify to juror irregularities such as intoxication."). See also Note, Pre-Deliberations Juror Misconduct, Evidential Incompetence and Juror Responsibility, 99 Yale L J 187 (1988).

23s See John Henry Wigmore, 8 Evidence $\S 2352$ at 696-97 nn 2 \& 3 (McNaughton rev) (Little, Brown 1961) (describing early English and American cases in which courts had received jurors' affidavits of misconduct without question).

${ }_{234} 1$ Term Rpts 11 (KB 1785).

238 "Nemo turpitudinem suam allegans audietur." See Wigmore, 8 Evidence 696 (cited in note 233). One of the jurors who approached the defense attorney in Tanner reported misconduct by other jurors, not herself. At least as originally formulated, the common law rule would not have excluded her testimony, for she did not "allege her own turpitude."

Lord Mansfield's far-reaching argument for excluding admissions of wrongdoing was simply that an admitted wrongdoer is unworthy of belief. If taken seriously, this argument would have required courts to exclude all confessions of crime.

236 Just as they repudiated other aspects of Lord Mansfield's work. See Grant Gilmore, The Ages of American Law 7-8 (Yale, 1977); W. S. Holdsworth, 8 A History of English Law 34-38 (Little, Brown, 1926). Lord Mansfield had pressed his favorite civil law maxim into the service of a long-sustained campaign to make virtually all commercial promises enforceable. He had ruled that a person who had signed a commercial instrument could not assert its invalidity on grounds of usury, for doing so would allege this person's own turpitude. Walton $v$ Shelly, 1 Term Rpts 296, 300 (KB 1786). This application of the doctrine lasted twelve years. See Jordaine v Lashbrooke, 7 Term Rpts 601, 603 (KB 1798) (Kenyon); John Henry Wigmore, 2 Evidence: Trials at Common Law, \$ 529 at 739 (Chadbourn rev) (Little, Brown 1979). 
ple nevertheless persisted to forbid jurors from impeaching their verdicts. In Wigmore's words, "supposed new reasons of policy were found."237

Wigmore noted the incongruity of admitting the testimony of a "bailiff whose shameless [intrusion] upon [the jury's] privacy forms his only qualification as a witness" while "sanctimoniously put[ting] away the juryman who reports his own misconduct."238 Our law regards admissions of wrongdoing as generally trustworthy, ${ }^{239}$ and accepting responsibility for one's misconduct is regarded as an admirable rather than a regrettable act. In Vaise $v$ Delaval, the Court inverted the usual principles of law and everyday morality. Moreover, Mansfield's rule presented other incongruities as well.

As applied both historically and today in the states that retain it, the rule is one-sided. It prohibits jurors from burying their verdicts but not from praising them. Thus, in a case in which a bailiff or other nonjuror alleges misconduct by a jury, the rule permits jurors to deny this misconduct but not to confess it. ${ }^{240} \mathrm{~A}$ rule that makes admissibility depend solely on whether a witness says what officialdom wishes to hear-one that admits a witness's testimony when it favors the state but not when it favors the defendant-violates basic principles of impartiality. Despite its historic pedigree, the rule is probably unconstitutional. ${ }^{241}$

${ }^{237}$ Wigmore, 8 Evidence $\S 2352$ at 696 (cited in note 233). For a discussion of these "supposed new reasons of policy," see text at notes 249-57.

23s Id $\S 2353$ at 699 .

${ }^{238}$ Most notably, an exception to the hearsay rule admits declarations against interest even when made by people who were unsworn and not subject to cross-examination. See, for example, United States $v$ Matlock, 415 US 164 (1979). See also United States v Harris, 403 US 573, 583 (1971) (plurality opinion) ("Admissions of crime, like admissions against proprietary interest, carry their own indicia of credibility-sufficient at least to support a finding of probable cause to search."). Most admissions of juror misconduct do not fall within the traditional hearsay exceptions for declarations against penal and proprietary interest. As the Tanner case illustrates, however, some do. Moreover, even when a juror's admission does not fall within the hearsay exceptions, it reveals personally embarrassing information and is apparently offered for the purpose of benefiting a wronged litigant rather than the juror himself or herself.

${ }^{240}$ See, for example, Smith v Illinois Valley Ice Cream Co., 20 Ill App 2d 312, 156 NE2d 361 (1959); State v Holt, 79 SD 50, 51-52, 107 NW2d 732, 733 (1961); Wigmore, 8 Evidence $\S 2354$ at 714 and $\mathrm{nn} 9,10$ (cited in note 233) (collecting cases).

${ }^{241}$ See Wardius $v$ Oregon, 412 US 470, 474 (1973) (unanimous ruling that a state may not obtain discovery from a defendant without affording him or her an opportunity to obtain similar discovery from the state-"although the Due Process Clause has little to say regarding the amount of discovery which the parties must be afforded, ... it does speak to the balance of forces ...."); Washington $v$ Texas, 388 US 14 (1967) (a state rule that does not preclude a criminal from testifying against an alleged accomplice but that does preclude him or her from testifying in favor of the alleged accomplice violates the Compulsory Pro- 
Moreover, as the Supreme Court noted in Tanner, Mansfield's rule, like the current Federal Rule, is subject to an important exception; jurors may testify to "extraneous" or "outside" influences that could have affected their deliberations. ${ }^{242}$ In some situations, this exception may be mandated by the Sixth Amendment right to confront one's accusers. ${ }^{243}$ The scope of the exception has proven problematic, and its application has yielded strange results.

Some courts have held, for example, that when a juror consults a dictionary to learn the meaning of terms used in the court's instructions, the dictionary is an improper "outside influence." The juror's testimony therefore can be received and the verdict set aside. $^{244} \mathrm{Had}$ the juror known or misunderstood the meaning of the words used by the court at the time that he or she heard them,

cess Clause of the Sixth Amendment); Pennsylvania $v$ Ritchie, 480 US 39, 51-61 (1987) (the Due Process Clause entitles a defendant to limited pretrial discovery of the records of a state agency so long as these records are available to courts and law enforcement personnel). Were the rule against "impeachment" of a person's own actions extended to officials other than jurors-for example, by precluding police officers from testifying to their unlawful searches or other violations of the Constitution while permitting them to deny allegations of civil rights violations made by others-courts probably would hold the rule unconstitutional without hesitation.

Unlike the traditional rule forbidding the impeachment of verdicts by jurors, Federal Rule of Evidence 606(b) does not make admissibility depend on which party the testimony favors. The Rule's evenhandedness sometimes causes it to work as unfairly to the state as it does to defendants. In Stockton v Virginia, 852 F2d 740 (4th Cir 1988), the Fourth Circuit noted that proof of an unauthorized and potentially prejudicial communication with jurors requires the government to demonstrate that the communication was harmless. In Stockton, however, in which a restaurant owner had urged some jurors dining in his restaurant to "fry the son of a bitch," Rule 606(b) prevented the jurors from testifying that they had not in fact been influenced by this improper communication. Id at 742, 744-45. Although the Rule plainly applied, a plausible reason for rejecting the jurors' testimony is difficult to envision. Moreover, in light of the fact that the federal rule is not truly "evidentiary" (see text at notes 249-50), its use in federal habeas corpus to prevent a state from proving the validity of a state criminal proceeding is offensive.

$242107 \mathrm{~S} \mathrm{Ct}$ at 2746.

24s See Parker v Gladden, 385 US 363, 364 (1966) (bailiff's comment to a juror that the defendant was guilty violated the Confrontation Clause); People v DeLucia, 20 NY2d 275, 229 NE2d 211, 214 (1967) (testimony that jurors had described their unauthorized view of a crime scene admitted-the jurors' statements had made them un-cross-examined witnesses against the defendant).

244 See, for example, Alvarez v People, 653 P2d 1127, 1131 (Colo 1982). But see id at 1133-35 (Rovira dissenting) (noting instances in which the Colorado Supreme Court had consulted and cited dictionaries). Although newspaper stories describing relevant but unadmitted evidence plainly qualify as "outside influences," some courts have concluded that dictionaries, law books, and medical treatises do not. See Annotation, Prejudicial Effect of Jury's Procurement or Use of Book During Deliberations in Criminal Cases, 35 ALR4th 626 (1985). Compare Jones v Kemp, 44 Crim L Rptr 2428 (N D Ga 1989) (state trial court committed constitutional error by permitting jurors in a capital case to consult the Bible, but "the use by deliberating jurors of an extrajudicial code . . . already embodied in their own characters" apparently would be permissible). 
however, his or her knowledge or misperception would have been an internal rather than an external influence. The fact that this knowledge or misperception would have proceeded from an extraneous source at some point in the juror's life would not have mattered.

Similarly, were a juror to seek guidance from an astrologer during the jury's deliberations, the astrologer would be an extraneous influence. Had the juror consulted the astrologer earlier and gained sufficient information to obtain guidance from the stars on his or her own, neither the astrologer nor the stars would have been viewed as an outside source of information. (Courts have in fact rejected testimony that jurors invoked astrology during their deliberations and reported supernatural visions. ${ }^{245}$ ) Both Mansfield's rule and Federal Rule 606(b) have led courts to focus on issues of timing and on the internal or external locus of improper sources of information. The rules have diverted courts from something that ought to be more important-the character of the information, misinformation, mind-altering chemicals, and supernatural visions that have led jurors to their verdicts.

In form, the rule against the impeachment of jury verdicts by jurors is merely an evidentiary rule. One must look elsewhere to discover the substantive grounds for setting jury verdicts aside. Since the mid-nineteenth century, American courts have in fact been divided on when proof of a juror's use of alcohol requires a new trial. A minority of courts have held that any unauthorized drinking even by a single juror requires a new trial and that inquiry into either the extent of this drinking or its effect is unnecessary. ${ }^{246}$ Most courts, however, have demanded some reason to be-

${ }^{245}$ See United States v Dioguardi, 492 F2d 70, 75 (2d Cir 1974) (juror wrote defendant that she had "eyes and ears that ... see things before it happen," claiming that "a curse was put on them some years ago"); State v DeMille, 756 P2d 81, 83 (Utah 1988) (juror claimed that she had received a divine sign of the defendant's guilt); Hutchinson $v$ Laughlin, 90 Ohio App 5, 102 NE2d 875 (1951) (astrological investigation by jury foreperson).

${ }^{246}$ See, for example, State v Baldy, 17 Iowa 39, 43 (1864) ("The parties have a clear right to the cool, dispassionate and unbiased judgment of each juror applied to the determination of the issues in the cause, and the use in any degree of that which stimulates the passions and has a tendency to lessen the soundness of judgment, is itself conclusive evidence that the party who has the right to the exercise of that dispassionate judgment, has been prejudiced in not having it as perfect as it existed in the juror when accepted ...."); People $v$ Schad, 58 Hun 571, 573-74, 12 NYS 695 (1891) ("[I]t is impossible for the court to measure or estimate the effect of an alcoholic stimulant, which varies with the susceptibility of the person by whom it is taken; it is enough that its well-known tendency is to produce an abnormal elevation, and, in the reaction, a corresponding depression of the mind and a consequent disturbance, in a greater or lesser degree of the reasoning powers."); Commonwealth $v$ Fisher, $226 \mathrm{~Pa} \mathrm{189,196-97,75a} \mathrm{204,} 207$ (1910) (defendant has a right to trial by 
lieve that the use of alcohol might have influenced the jury's performance. As the Nevada Supreme Court stated the rule in 1872 , "A judge . . . should never hesitate to set aside a verdict, in a criminal case, where there is even a suspicion that any juror was in the least affected by intoxicating liquor during the progress of the trial or the deliberation upon the verdict."247 Under any of the standards that American courts have employed, the alcohol and drug abuse described in Tanner would have led to a new trial if proven by witnesses other than the jurors. ${ }^{248}$

As the Supreme Court noted in Tanner, one asserted objective of Federal Rule 606(b) and of the rule against the impeachment of jury verdicts by jurors is to promote the finality of jury verdicts. ${ }^{249}$ Nevertheless, finality is disrupted as much by proof of juror misconduct from eavesdroppers, bartenders, and drug dealers as by proof from the jurors themselves. The evidentiary rules promote finality in a haphazard, backhanded way, relying on the fact that no one other than jurors usually is able to testify to their misconduct. Indeed, the claim that the rules promote finality strips away their evidentiary costume. One avowed function of these supposedly evidentiary rules is simply to abrogate the substantive rules that purport to entitle litigants to relief from improper jury verdicts.

Considerations of finality might justify requirements of timeliness in filing motions for new trials and limitations of the substantive bases for setting jury verdicts aside. Our goal sometimes may be: the right answer if possible but above all an answer. Nevertheless, after devoting substantial resources to the selection of an impartial jury, permitting lawyers to probe the private lives of prospective jurors in an effort to accomplish this goal, allowing

jurors who are "above suspicion of being intoxicated"). For a review of early decisions holding that "Courts will not inquire whether the juror was affected by what he drank" and that "the only sure safeguard to the purity and correctness of the verdict is that no drinking shall be allowed," see People v Gray, 61 Cal 164, 184 (1882).

${ }^{247}$ State $v$ Jones, $7 \mathrm{Nev} 408,414-15$ (1872). See generally Annotation, Use of Intoxicating Liquor by Jurors: Criminal Cases, 7 ALR3d 1040 (1966).

${ }^{248}$ The trial judge in Tanner in fact invited the defense attorney to present proof of the jurors' drug and alcohol abuse from a source other than the jurors themselves. $107 \mathrm{~S} \mathrm{Ct}$ at 2744. During the nineteenth century, some courts invoked the rule against the impeachment of jury verdicts by jurors to preclude jurors from testifying to their own intoxication. Other courts, however, did consider this testimony. See Perry v Bailey, 12 Kan 539, 544-45 (1874); March v State, 44 Tex 64, 84 (1875).

240 See $107 \mathrm{~S} \mathrm{Ct}$ at 2747 ("Allegations of juror misconduct, incompetency, or inattentiveness, raised for the first time days, weeks, or months after the verdict seriously disrupt the finality of the process."); Advisory Committee's Note, FRE 606(b) at 58 (cited in note 227). 
lawyers to challenge prospective jurors peremptorily because a mysterious sixth sense may offer a hint of partisanship, wrangling over evidentiary issues to ensure that jury verdicts rest on better information than is employed in most of life's decisions, and debating and delivering lengthy instructions on the law, it is odd to reject highly probative evidence that the process did not work. The Tanner decision illustrates a central dynamic of American criminal justice: Millions for procedure but not one dime for outcome. ${ }^{250}$

The Supreme Court argued in Tanner that rules forbidding the impeachment of jury verdicts by jurors promote "full and frank discussion in the jury room, jurors' willingness to return an unpopular verdict, and the community's trust in a system that relies on the decisions of laypeople." ${ }^{251}$ Again, however, the effect of any revelation of jury misconduct on the quality of future jury deliberations and on the public's acceptance of jury verdicts seems unaffected by whether the revelation comes from jurors or from some other source.

Moreover, unlike grand jurors, ${ }^{252}$ petit jurors are under no legal obligation to preserve the confidentiality of their deliberations. Jurors may (and do) tell newspaper reporters what transpired in jury rooms, reenact their deliberations on television broadcasts, and testify about these deliberations before legislative committees. ${ }^{253}$ If the prospect that jurors will recount the conduct of other jurors in these forums does not inhibit frank discussion, discourage jurors from taking unpopular stands, and undermine the public's confidence in jury verdicts, it seems doubtful that the prospect of disclosure in a court of law would do so. Our legal system fosters confidentiality by forbidding disclosure only when disclosure would save a defendant from wrongful punishment. We permit disclosure for the sake of informing and entertaining the public and amusing friends at cocktail parties.

Finally, the Tanner opinion argued that jurors would be "harassed and beset" by defeated litigants if they were permitted to testify to their misconduct. ${ }^{254}$ Alone among the arguments cur-

${ }^{250}$ To be sure, our profligate procedures are mostly on paper; we provide trials to only a small minority of defendants.

${ }^{281} 107$ S Ct at 2748. Compare Glanville Williams, The Proof of Guilt: A Study of the English Criminal Trial 268 (Stevens, 3d ed 1963) (Secrecy "preserve[s] public confidence in a system which more intimate knowledge might destroy.").

${ }^{262}$ See FRCrP 6(e).

${ }^{253}$ See Note, Public Disclosures of Jury Deliberations, 96 Harv L Rev 886 nn 4-5, 887 n 10 (1983).

${ }^{254} 107 \mathrm{~S}$ Ct at 2747 (quoting McDonald $v$ Pless, 238 US 264, 267-68 (1915)). 
rently offered for Mansfield's rule and its successors, this rationale would not extend to the testimony of nonjurors. Nevertheless, a more direct way to preclude harassment by lawyers and litigants would be to forbid harassment by lawyers and litigants. Some American jurisdictions currently require attorneys to obtain judicial leave before contacting jurors to discuss their verdicts; other jurisdictions do not. ${ }^{255}$ With judicial leave or without it, lawyers frequently approach jurors to conduct post-mortems. ${ }^{256}$ Courts might limit this practice without excluding the testimony of jurors whose unsolicited allegations of misconduct apparently have proceeded from pangs of conscience-jurors like those in Tanner. Moreover, if the prospect of obtaining proof of improper "external" influences like dictionaries and news broadcasts does not lead lawyers and litigants to harass and beset jurors, it seems unlikely that the prospect of obtaining proof of "internal" influences like cocaine and marihuana would do so.

The justifications offered for the rule against the impeachment of jury verdicts by jurors seem thin, and one may wonder whether this rule has served other goals that courts have been reluctant to avow. Justice O'Connor's opinion for the Court in Tanner may have hinted at these darker purposes:

There is little doubt that post-verdict investigation into juror misconduct would in some instances lead to the invalidation of verdicts reached after irresponsible or improper juror behavior. It is not at all clear, however, that the jury system could survive such efforts to perfect it. ${ }^{257}$

This statement, if translated into forthright English, might read, "We could not have a jury system if we faced the truth about it. We want to have a jury system, and we will therefore hide the truth." The refusal to know embodied in our rules may reflect what we know already-that our system of jury controls frequently fails. If verdicts could be set aside whenever jurors had misconstrued or defied the court's instructions, rendered compromise verdicts, considered for one purpose evidence admitted only for another, given substantial weight to evidence not admitted at all, treated a defendant's failure to testify as evidence of guilt, or acted

${ }^{26 s}$ See Annotation, Propriety of Attorney's Communications with Jurors After Trial, 19 ALRAth 1209, 1212 (1983).

2so See Marjorie Fargo, Make the Post-Trial Interview Work for You, 3 Crim Just 2 (Summer 1988).

$257107 \mathrm{~S} \mathrm{Ct}$ at 2747. 
on the basis of manifest prejudice, substantial numbers of jury verdicts might not stand. ${ }^{268}$

Perhaps what we say that we want juries to do and what we truly want them to do are different things. On the one hand, we tell juries to follow the law; on the other hand, when juries do not follow the law, they serve the purposes of the jury system. Lawlessness in verdicts of acquittal, however, is more tolerable than lawlessness in verdicts of conviction. ${ }^{289}$ Refusing to punish people whom the law declares punishable sometimes may thwart official oppression; punishing people whom, on a fair determination of the facts, the law would set free is not one of the jury system's virtues. A legal system that would knowingly permit a drunken, dozing tribunal of the sort described in Tanner to send people to prison ${ }^{260}$ has little claim to respect. ${ }^{261}$

Abandoning their hear-no-evil posture would require courts to confront difficult questions of how much juror misconduct these courts should endure. ${ }^{262}$ Refusing to face these questions, however,

${ }^{258}$ See Jerome Frank, Courts on Trial: Myth and Reality in American Justice 115 (Princeton, 1949); Fleming James, Jr. and Geoffrey C. Hazard, Jr., Civil Procedure 310 (Little, Brown, 2d ed 1977).

${ }^{230}$ See, for example, United States $v$ Scott, 437 US 82, 91 (1978) ("[T]he law attaches particular significance to an acquittal. To permit a second trial after an acquittal, however mistaken the acquittal may have been, would present an unacceptably high risk that the Government ... might wear down the defendant so that 'even though innocent, he may be found guilty." ") (quoting Green v United States, 355 US 184, 188 (1957)).

${ }^{280}$ Each of the defendants in Tanner was sentenced to 18 months' imprisonment. After the Supreme Court's decision, however, a panel of the United States Court of Appeals for the Eleventh Circuit vacated the defendants' convictions on grounds unrelated to the alleged jury misconduct. United States v Conover, 845 F2d 266 (11th Cir 1988). At last word, the Eleventh Circuit had not acted on the government's petition for en banc rehearing of the panel decision. Letter from John A. DeVault, III, defendants' counsel, to author, July 22, 1988 (on file, University of Chicago Law Review office).

${ }^{261}$ See, for example, Russell v State, 53 Miss 367, 382 (1876) ("Nothing can be more revolting to a sense of justice or decency than the idea of the life or liberty of a citizen depending upon the maudlin deliberations of drunken jurors.").

${ }^{262}$ Abandoning traditional doctrine, courts might conclude that the presence of a substantial number of jurors whose behavior remained unimpeached could provide an adequate internal corrective for the bias, incompetence or misconduct of a few. In situations in which the judiciary had no opportunity to correct the error prior to the verdict, the misconduct or misunderstanding of a minority of the jury might be treated as harmless so long as a substantial majority (say, five members of a six person jury or nine or ten of a twelve person jury) apparently had performed properly. See Brief for the United States at 49-50 n 35, Tanner v United States, 107 S Ct 2739 (1987); but see Parker v Gladden, 385 US 363, 366 (1966) (even when conviction by a nonunanimous jury is permissible, a defendant is "entitled to be tried by 12 , not 9 or even 10, impartial and unprejudiced jurors"). In states that permit nonunanimous verdicts, a rule permitting jurors to impeach their verdicts might conceivably lead outvoted jurors deliberately to engage in misconduct in the hope that this misconduct would invalidate a verdict approved by the majority. Although this danger 
subjects criminal defendants to punishment on the basis of bias, incompetence, and caprice, mocking our claim of adherence to the rule of law. Reality does not evaporate when courts refuse to receive proof of it.

Overshadowing our evidentiary rules is a constitutional command: "In all criminal prosecutions, the accused shall enjoy the right to a speedy and public trial, by an impartial jury ...."263 The Supreme Court held in Tanner that the trial court's refusal to consider the jurors' testimony did not deprive the defendants of this Sixth Amendment right. ${ }^{264}$ In retrospect, it seems unfortunate that the authors of the Sixth Amendment failed to write it somewhat differently: "In all criminal prosecutions, the accused shall enjoy the right to a speedy and public trial, by an impartial, awake, and unstoned jury." The Framers may have thought that some things went without saying; and in Tanner, the Supreme Court shunted aside an elemental violation of due process principles.

\section{Conclusion: A Fair and Workable Jury System}

This article has focused primarily on three recent Supreme Court decisions concerning the jury. Together they depict a criminal justice system without clear priorities in which symbols have become more important than substance-a system dominated by pragmatism and the hope of muddling through rather than by visions and hopes of justice.

In McKleskey $v$ Kemp, ${ }^{265}$ the Supreme Court declined to hold America's racially discriminatory administration of the death penalty unconstitutional. In Turner $v$ Murray, ${ }^{266}$ however, it manifested a symbolic opposition to racial discrimination by requiring prospective jurors in some capital cases to answer an insulting question. The Court added one more gargoyle to the front end of the temple of justice while turning its eyes from back-end outcomes. The Court's approach appeared to be, "Procedure yes, substance no."

In Batson $v$ Kentucky, ${ }^{287}$ the Supreme Court did not prevent prosecutors and defense attorneys from discriminating on many in-

seems small (and unsubstantiated by evidence that jurors have sought to subvert verdicts by engaging in the sorts of misconduct that courts currently consider), the risk might support a requirement of proof of misconduct on the part of more than one or two jurors.

${ }_{203}$ US Const, Amend VI.

284 $107 \mathrm{~S} \mathrm{Ct}$ at $2750-51$.

285481 US 279 (1987).

266476 US at 28 . See text at notes $21-36$.

${ }^{267} 476$ US 79 (1986). 
vidious grounds in the selection of trial jurors. In a largely symbolic display of opposition to one form of discrimination, however, it built another front-end gargoyle-one that dwarfs the Turner $v$ Murray statuary in its ugliness and size. The Court devised burdensome procedural mechanisms to generate disturbing substantive outcomes-for example, that it is permissible to exclude from a jury "the Dallas prosecutor's nightmare," man schoolteacher from New Jersey with a limp who is both black and Jewish and who never goes hunting.

In Tanner $v$ United States, ${ }^{269}$ the Court that had invented the Batson hearing upheld convictions returned by a group of apparently drugged, drunken, and dozing jurors. When the issue was the review of a jury's back-end product rather than the proliferation of front-end procedures, considerations of judicial economy became important. There was no indication in Tanner that the prosecutor had exercised his peremptory challenges improperly or that the partying jury had failed to include an appropriate number of blacks and whites. In our criminal justice system, that deficiency apparently would have been more serious than the jurors' abuse of alcohol, marihuana, and cocaine, and the defendants would have been entitled to post-conviction relief.

Overshadowing the other ironies of the Supreme Court's jurytrial decisions is the rarity of jury trials in the American system of criminal justice. For the overwhelming majority of defendants, most refinements of voir dire procedure either do not matter or matter primarily because they make jury trials less accessible. Battles over trial procedures typically disregard the pressures that our legal system places on defendants to abandon the right to jury trial. A system that can afford Batson hearings and that can expend its resources asking prospective jurors whether they are bigots apparently cannot afford to provide trials to the people it accuses of crime. Again, symbols appear more important than substance.

Jury trials once were simple, straightforward, and expeditious proceedings; and the right to jury trial was a right that defendants got, not merely one that they had. ${ }^{270}$ Simplifying our trial processes could reduce the perception that widespread subversion of the right to jury trial is necessary.

${ }^{283}$ See text at note 199.

$269107 \mathrm{~S}$ Ct 2739 (1987).

${ }^{270}$ See Langbein, $45 \mathrm{U}$ Chi L Rev 263 (cited in note 216); Albert W. Alschuler, Plea Bargaining and Its History, 79 Colum L Rev 1, 16, 33 (1979). 
The principal argument for jury trials can be stated in a word-judges. ${ }^{271}$ In 1917 , G. K. Chesterton added more words and made this argument more eloquently:

Now, it is a terrible business to mark a man out for the vengeance of men. But it is a thing to which a man can grow accustomed, as he can to other terrible things ..... And the horrible thing about all legal officials, even the best, about all judges, magistrates, barristers, detectives, and policemen, is not that they are wicked (some of them are good), not that they are stupid (several of them are quite intelligent), it is simply that they have got used to it.

Strictly, they do not see the prisoner in the dock; all they see is the usual man in the usual place. They do not see the awful court of judgment; they see only their own workshop. Therefore, the instinct of Christian civilisation has most wisely declared that into their judgments there shall upon every occasion be infused fresh blood and fresh thoughts from the streets. Men shall come in who can see the court and the crowd, and coarse faces of the policemen and professional criminals, the wasted faces of the wastrels, the unreal faces of the gesticulating counsel, and see it all as one sees a new picture or a ballet hitherto unvisited.

Our civilisation has decided, and very justly decided, that determining the guilt or innocence of men is a thing too important to be trusted to trained men. ${ }^{272}$

Lay jurors have distinctive virtues in conducting the "business [of] mark[ing] a man out for the vengeance of men." They also have distinctive vices. Law-trained judges often may be alert to governmental abuses in ways that nonprofessionals are not. I have argued elsewhere that mixed tribunals of lay and professional judges of the sort found on the European continent might best utilize the distinctive characteristics of both groups in resolving issues of guilt and punishment. ${ }^{273}$

In light of the virtues of mixed tribunals, the Supreme Court's

${ }^{271}$ See Duncan $v$ Louisiana, 391 US 145,156 (1968) (the right to jury trial guards against "the compliant, biased, or eccentric judge").

${ }^{272}$ Gilbert Keith Chesterton, Tremendous Trifles 80, 85-86 (Dodd, Mead, 1917).

${ }^{273}$ Albert W. Alschuler, Implementing the Criminal Defendant's Right to Trial: Alternatives to the Plea Bargaining System, 50 U Chi L Rev 931, 997-1011 (1983). 
decision in Duncan $v$ Louisiana, ${ }^{274}$ a decision generally understood as precluding the states from experimenting with alternatives to the jury trial, was probably unfortunate. Although I have argued that Duncan may not in fact be as restrictive of departures from the jury system as most observers assume, ${ }^{275} \mathrm{I}$ also have recognized that, for the moment, the prospect of employing mixed tribunals or other alternatives to the jury trial in American felony cases is "probably a pipe dream."276

American trial procedures could be simplified, however, either by departing from the jury trial format or by making greater efforts to realize the virtues of this format. The appropriate alternative to departing from the jury trial is adhering to its ideals. The American jury trial has become unworkable largely because we have tried to have things both ways, sometimes romanticizing jurors as zealous yeomen alert to abuses of governmental power and sometimes treating them as helpless, weak-minded, irrational, vindictive, and easily swayed children.

If we accepted the democratic rhetoric of the jury system, we would select juries so that they reflected the breadth of our communities rather than the group left over when lawyers had expended their peremptory challenges on pet hates. Accepting the premises of the jury system would mean viewing jurors neither as child savants nor as child simpletons but as responsible adults. It would mean abandoning our cumbersome, patronizing rules of evidence and trusting jurors with the facts. It would mean respecting the jurors' privacy, abandoning our probing of their psyches, beliefs, and practices in extended voir dire examinations. It would mean permitting prospective jurors to serve on juries unless, after asking only the questions needed to uncover interests and biases that would equally disqualify professional judges, grounds for their recusal appeared.

Treating jurors as grown-ups would demand that they, no less than trial judges and other officials, be held to adult standards of responsibility. Viewing as sacrosanct the back-end product of jury trials while relying almost entirely on front-end controls to prevent injustice is fundamentally unsound. The front-end controls are cumbersome, expensive, wasteful and weak. Courts should not turn aside clear proof in particular cases that these controls have failed. The Supreme Court has held that the Fifth Amendment's Double

274 391 US 145 (1968).

${ }^{275}$ Alschuler, $50 \mathrm{U}$ Chi L Rev at 995-97 (cited in note 273).

${ }^{278}$ Id at 1010. 
Jeopardy Clause precludes the review of jury verdicts of acquittal, ${ }^{277}$ but nothing in the Constitution forbids judicial review of the appropriateness of criminal convictions. Judges need neither imprison defendants whom they believe to be innocent nor uphold convictions by jurors who have abandoned their responsibilities.

Just as the jury system provides a safeguard against the excesses, insensitivities, and biases of judges, judges should check the excesses, insensitivities, and biases of jurors. Bringing the distinct perspectives of jurors and professional judges to bear on an issue promotes greater confidence in its resolution than yielding the decision to either lay or professional judges alone. As Chesterton suggested, determining guilt or innocence may be "a thing too important to be trusted to trained men,"278 but it is also a thing too important to be trusted to anyone in the absence of the sort of oversight and review afforded the actions of most governmental officials. Justice Black's opinion for the Court in Toth $v$ Quarles ${ }^{279}$ struck an appropriate balance:

Juries fairly chosen from different walks of life bring into the jury box a variety of different experiences, feelings, intuitions and habits.... On many occasions, fully known to the Founders of this country, jurors-plain people-have ... stood up in defense of liberty against the importunities of judges and despite prevailing hysteria and prejudices .... Unfortunately, instances could also be cited where jurors have themselves betrayed the cause of justice by verdicts based on prejudice or pressures. In such circumstances independent trial judges and independent appellate judges have a most important place under our constitutional plan ....

${ }^{277}$ See, for example, United States $v$ Ball, 163 US 662, 671 (1896); United States $v$ Scott, 437 US 82 (1978).

${ }^{278}$ See text at note 272 .

279350 US 11, 18-19 (1955). 